\title{
Traditional and new POPs in environments along the Bohai and Yellow Seas: An overview of China and South Korea
}

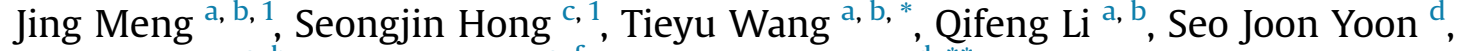 \\ Yonglong Lu ${ }^{\text {a, b }}$, John P. Giesy ${ }^{\text {e, }}$, Jong Seong Khim ${ }^{\text {d, }}$.* \\ a State Key Lab of Urban and Regional Ecology, Research Center for Eco-Environmental Sciences, Chinese Academy of Sciences, Beijing 100085, China \\ b University of Chinese Academy of Sciences, Beijing 100049, China \\ ${ }^{\mathrm{c}}$ Department of Ocean Environmental Sciences, Chungnam National University, Daejeon 34134, Republic of Korea \\ d School of Earth and Environmental Sciences \& Research Institute of Oceanography, Seoul National University, Seoul 08826, Republic of Korea \\ e Department of Veterinary Biomedical Sciences \& Toxicology Centre, University of Saskatchewan, Saskatoon, SK, Canada \\ ${ }^{\mathrm{f}}$ Department of Zoology \& Center for Integrative Toxicology, Michigan State University, East Lansing, MI, USA
}

\section{H I G H L I G H T S}

- Spatio-temporal distribution of classic and emerging POPs along Yellow Sea reviewed.

- Hot spots for POPs pollution and associated sources or local activities characterized.

- Sources of target POPs were independent each other both in local and national scale.

- OCPs, PCBs and PFASs were widely contaminated groups in China and South Korea.

\section{A R T I C L E I N F O}

\section{Article history:}

Received 18 September 2016

Received in revised form

18 November 2016

Accepted 20 November 2016

Available online 25 November 2016

Handling Editor: Shane Snyder

\section{Keywords:}

POPs

Distribution

Sediment

Water

Risk assessment

Asia

\begin{abstract}
A B S T R A C T
Rapid economic growth during the past two decades in the region surrounding the Bohai and Yellow Seas has resulted in severe pollution. Large amounts of monitoring data on persistent organic pollutants (POPs) in various environmental media have been accumulated, which allows us to conduct a fairly comprehensive assessment of the region around the Bohai and Yellow Seas to elucidate spatial patterns of pollution on a regional scale. This review summarized distributions of traditional and new POPs, including organochlorine pesticides (OCPs), polychlorinated biphenyls (PCBs), polybrominated diphenyl ethers (PBDEs), hexabromocyclododecanes (HBCDs), and perfluoroalkyl substances (PFASs), in various environmental media. In general, due to their physico-chemical properties (poor solubility in water), OCPs and PCBs were mainly detected in sediments, PBDEs and HBCDs were mainly detected in sediments and soils. PFASs, which have greater solubility, were mainly detected in the hydrosphere. For conventional POPs, such as OCPs and PCBs, Bohai Bay and Haihe River in China, Gyeonggi Bay and Lake Sihwa in South Korea were found to be most polluted areas. While for new POPs, such as PBDEs, HBCDs and PFASs, some areas were heavily polluted due to local production and applications. Estuarine and coastal areas of the Bohai Sea were more severely contaminated by POPs than coastal regions of the Yellow Sea. Overall, the present review will guide identification of key areas for strengthening risk assessment of POPs and management practices.
\end{abstract}

๑) 2016 Elsevier Ltd. All rights reserved.

\footnotetext{
* Corresponding author. State Key Lab of Urban and Regional Ecology, Research Center for Eco-Environmental Sciences, Chinese Academy of Sciences, Beijing 100085, China.

** Corresponding author.

E-mail addresses: wangty@rcees.ac.cn (T. Wang), jskocean@snu.ac.kr (J.S. Khim).

1 These authors contributed equally to this work.
}

\section{Introduction}

Persistent organic pollutants (POPs) have been of great concern during the last few decades due to: a) persistence, b) long-range transport, c) potential to be bioaccumulated by organisms, and d) potential toxic effects on humans and wildlife (Nadal et al., 2015). The Stockholm Convention on POPs aims to protect humans and 
the environment from hazardous and persistent chemicals by reducing or eliminating their production and emission. The convention, which was adopted in 2001, came into force in 2004. The initial list included twelve chemicals called the "dirty dozen", which included organic chlorinated pesticides (OCPs) (including dichlorodiphenyltrichloroethanes, DDTs) and polychlorinated biphenyls (PCBs) (UNEP, 2001). In 2009, nine new chemicals were added and came into force one year later. The added chemicals included hexachlorocyclohexanes (HCHs), polybrominated diphenyl ethers (PBDEs) and perfluoroalkyl substances (PFASs) (e.g., perfluorooctane sulfonic acid (PFOS) and its salts, perfluorooctane sulfonyl fluoride) (UNEP, 2009). Hexabromocyclododecanes (HBCDs) were also listed in Annex A of the Stockholm Convention on POPs in 2013 (UNEP, 2013).

HCHs and DDTs are two main components of OCPs that historically have been used extensively in agriculture and sanitation (Zhang et al., 2013a). PCBs are widely used in transformers, capacitors, and printing ink, among which trichlorobiphenyl with pentachlorobiphenyl is the most prevalent congener (Erickson and Kaley, 2011). PBDEs, often produced as penta-, octa-, and deca-BDE commercial mixtures, are major constituents of brominated flame retardants (BFRs) broadly used in electronics and household products (La Guardia et al., 2006). Penta-BDE and octa-BDE have been banned due to the adverse effects on biota and their increasing concentrations in the environment. However, deca-BDE is still being produced and used (Zhu et al., 2009). HBCDs have become an important alternative BFR after production and use of PBDEs were restricted (Xia et al., 2011). They are primarily added into expanded and extruded polystyrene which are used in building insulation, and are also employed in electrical equipment, great impact polystyrene and textile coatings (POPRC, 2011). PFASs have been widely used in the past six decades as additives in surface coatings of carpets, leather, papers, and textiles, as well as in firefighting foams, pesticides, paints, etc. PFOS and perfluorooctanoic acid (PFOA) are the most frequently detected PFASs in the environments (Kannan, 2011).

Distributions of POPs in environmental media are strongly dependent on their physico-chemical properties (Wania and Mackay, 1996). POPs have generally hydrophobic nature with log $\mathrm{K}_{\mathrm{ow}}$ values ranging from 3 to 7 (Jones and De Voogt, 1999; Kelly et al., 2007). Thus, POPs have low water solubility, great bioaccumulation potential, low rates of degradation, and high adsorption onto sediments. When POPs are transported from river to estuary, due to the great ionic strength, solubility of POPs decreases in seawater compared to that in freshwater. Consequently, adsorption of POPs onto suspended particles and sediments increases in estuarine areas (Hong et al., 2013; Turner and Millward, 2002; Turner and Rawling, 2001). Thus, POPs are largely scavenged by adsorption onto suspended particles, less delivered to remote regions by oceanic current, and accumulated in sediments in estuarine and coastal areas. Finally, POPs can persist in coastal sediments for long periods of time and can cause adverse effects on benthic organisms. However, water soluble POPs, such as PFASs occurred in water column and can be delivered to remote regions by oceanic currents (Hong et al., 2013, 2015; Naile et al., 2010).

The Yellow and Bohai Seas, together with surrounding coastal areas, are major commercial zones and have undergone massive urbanization and industrialization. As one of the most developed regions, they are surrounded by several metroplexes, such as the Chinese cities of Beijing, Tianjin, Dalian and Qingdao, and Korean cities including Seoul, Incheon, Asan, Gunsan, and Mokpo. Intensive anthropogenic activities in these regions have severely deteriorated environmental quality, especially along the coast (Hong et al., 2012, 2016; Naile et al., 2010, 2011, 2013). Several rivers, including the Liaohe, Haihe and Yellow from China, and the Han, Geum and
Youngsan from South Korea, empty into the Bohai and Yellow Seas, respectively. Industrial and municipal wastewater from surrounding cities is also discharged. In addition, the semi-enclosed terrain makes exchange of water between the Bohai and Yellow Seas and the open ocean relatively slow. Thus, pollutants tend to be contained in these rather enclosed areas. The Bohai and Yellow Seas together, have become one of the most heavily polluted sea areas and thus act as a sink and possible long-term source of pollutants including POPs. In addition, the Bohai and Yellow Seas are also one of the most important fishery stocks, and they provide amounts of seafood to peripheral cities. Therefore, pollution as a potential source of exposure of humans, has caused concerns in the past decades. This review will support basic information to master overall pollution status and assess ecological risks, while help scientists identify future research direction.

\section{Review methodology}

Contamination of environmental media by POPs along the Bohai and Yellow Seas in China and South Korea, respectively, have been extensively studied during the last 20 years. Large amounts of monitoring data on POPs have been accumulated which allow us to conduct a fairly comprehensive assessment of coastal areas of China and South Korea and elucidate spatial patterns of pollution on a regional scale.

In the present study, we collected and reviewed results of previous studies on POPs in environmental media, such as sediments, soils, and water from the Bohai and Yellow Seas, specifically including Bohai Sea and north Yellow Sea from Dalian Bay to Haizhou Bay in China, and West Sea of South Korea from north Incheon Harbor to south Youngsan River. POPs focused on: a) chlorinated POPs (OCPs and PCBs), b) brominated POPs (PBDEs and HBCDs), and c) fluorinated POPs (PFASs) (Table 1). A total of 101 previous studies on distributions of POPs in environmental media were reviewed (details in Tables S1 and S2 in Supplementary Materials).

Study efforts on each chemical group were generally comparable except for new POPs such as PBDEs and HBCDs. Among the environmental media, POPs in sediments have been extensively studied, followed by soils and water. In particular, because of their low solubility in water and hydrophobic characteristics, studies of POPs except for PFASs in water samples were scarce. Thus, in the present study, distributions of POPs focused on OCPs, PCBs, PBDEs and HBCDs in sediments and PFASs in water collected from the area in and surrounding the Bohai and Yellow Seas. At the beginning of studies of POPs, most studies were limited to reporting concentrations of traditional POPs such as OCPs and PCBs. Later, several studies have reported information on new POPs, such as PBDEs, HBCDs and PFASs.

In both China and South Korea, studies of POPs in sediments have shown a preponderance of certain areas, such as greatly polluted regions (Table 1 and Fig. 1). Fifteen regions in areas surrounding the Bohai Sea and north Yellow Sea in China, including: Dalian Bay, Liaohe River, Daliao River, Shuangtaizi River, Daling River, Liaodong Bay, Haihe River, Tianjin, Bohai Bay, Yellow River, Xiaoqing River, Laizhou Bay, Qingdao, Jiaozhou Bay, and Haizhou Bay and nine regions of the West Sea of South Korea, including: Incheon Harbor, Gyeonggi Bay, Lake Sihwa, Namyang Bay, Asan Bay, Taean Coast, Geum River, Saemangeum Coast, and Youngsan River have been studied.

In the present study, we collected and reviewed major findings that determined pollution of POPs in environmental media (sediments, soils and water) of the Bohai and Yellow Seas during the past two decades. The present article is aimed to specifically document spatial distribution, sources and potential risks of five groups of 
Table 1

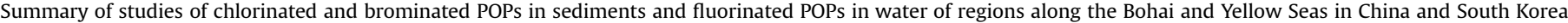
(locations are presented in Fig. 1).

\begin{tabular}{|c|c|c|c|c|c|c|c|}
\hline \multirow[t]{2}{*}{ Countries and regions } & \multirow[t]{2}{*}{ Types } & \multirow[t]{2}{*}{ Survey year } & \multicolumn{2}{|c|}{ Chlorinated POPs } & \multicolumn{2}{|c|}{ Brominated POPs } & \multirow{2}{*}{$\frac{\text { Fluorinated POPs }}{\text { PFASs }}$} \\
\hline & & & OCPs & PCBs & PBDEs & HBCDs & \\
\hline \multicolumn{8}{|l|}{ Chinese Coasts } \\
\hline C1. Dalian Bay & B & 1996 & V & & & & \\
\hline C2. Liaohe River & E, R & 2004-2005, 2009-2010, 2012, 2015 & $\mathrm{~V}$ & V & $\mathrm{V}$ & & $\mathrm{V}$ \\
\hline C3. Daliao River & $\mathrm{B}, \mathrm{E}$ & $1996,2001-2007$ & $\mathrm{~V}$ & $\mathrm{~V}$ & $\mathrm{~V}$ & & \\
\hline C4. Shuangtaizi River & $\mathrm{E}$ & 2013 & V & $\mathrm{V}$ & & & \\
\hline C5. Daling River & $\mathrm{R}$ & 2009, 2011 & & & & & V \\
\hline C6. Liaodong Bay & E & 2008,2013 & & & & & $\mathrm{~V}$ \\
\hline C7. Haihe River & E, R & $2004,2006,2007-2010$ & $\mathrm{~V}$ & $\mathrm{~V}$ & $\mathrm{~V}$ & & $\mathrm{~V}$ \\
\hline C8. Tianjin & E & 2009,2010 & & & V & $\mathrm{V}$ & \\
\hline C9. Bohai Bay & $\mathrm{B}, \mathrm{C}, \mathrm{E}$ & $2004,2006-2013$ & $\mathrm{~V}$ & V & $\mathrm{V}$ & & V \\
\hline C10. Yellow River & E & 2012 & $\mathrm{~V}$ & & & & \\
\hline C11. Xiaoqing River & $\mathrm{R}$ & 2014 & & & & & $\mathrm{~V}$ \\
\hline C12. Laizhou Bay & $\mathrm{B}, \mathrm{E}, \mathrm{R}$ & 2007, 2009-2010, 2014 & & & V & V & \\
\hline C13. Qingdao & $\mathrm{C}$ & 2006,2007 & & V & & & \\
\hline C14. Jiaozhou Bay & $\mathrm{B}, \mathrm{C}$ & 1996, 2006-2007, 2009, 2014 & $\mathrm{~V}$ & $\mathrm{~V}$ & & $\mathrm{~V}$ & \\
\hline C15. Haizhou Bay & $\mathrm{C}$ & 2001 & & $\mathrm{~V}$ & & & \\
\hline \multicolumn{8}{|l|}{ Korean Coasts } \\
\hline K1. Incheon Harbor & B & 1996, 2001-2003, 2005-2007 & $\mathrm{V}$ & $\mathrm{V}$ & V & $\mathrm{V}$ & \\
\hline K2. Gyeonggi Bay & $\mathrm{B}, \mathrm{R}$ & 1996, 2000-2005, 2008-2009, 2012 & $\mathrm{~V}$ & $\mathrm{~V}$ & $\mathrm{~V}$ & $\mathrm{~V}$ & $\mathrm{~V}$ \\
\hline K3. Lake Sihwa & $\mathrm{I}, \mathrm{L}$ & $1996,1998,2000,2005,2008-2012$ & $\mathrm{~V}$ & $\mathrm{~V}$ & $\mathrm{~V}$ & $\mathrm{~V}$ & $\mathrm{~V}$ \\
\hline K4. Namyang Bay & B & 1996 & $\mathrm{~V}$ & & & & \\
\hline K5. Asan Bay & B & 2001-2003, 2005, 2008, 2010-2012 & $\mathrm{V}$ & $\mathrm{V}$ & & & V \\
\hline K6. Taean Coast & $\mathrm{C}$ & 2001-2003, 2008, 2010-2012 & $\mathrm{V}$ & $\mathrm{V}$ & & & $\mathrm{V}$ \\
\hline K7. Geum River & E, R & $2001-2004,2008-2012$ & $\mathrm{~V}$ & $\mathrm{~V}$ & & & V \\
\hline K8. Saemangeum Coast & $\mathrm{C}, \mathrm{R}$ & 2001-2003, 2006-2007, 2009 & $\mathrm{~V}$ & $\mathrm{~V}$ & & & $\mathrm{~V}$ \\
\hline K9. Youngsan River & B, C, E, I, R & 2001-2003, 2006-2012 & V & V & & & V \\
\hline Data present in & & & Fig. 2 & Fig. 3 & Fig. 4a & Fig. 4b & Fig. 5 \\
\hline
\end{tabular}

B: bay; C: coast; E: estuary; I: inland; L: lake; R: river.

POPs in the environment for future monitoring and risk assessment use. Overall, the present review would provide the most up-to-date information, list of studies on POPs in the Bohai Sea and Yellow Sea regions, and better understanding on pollution of POPs. In addition, this study will guide identification of hotspot areas and prioritization of research needed concerning monitoring, assessments, and management practices of POPs.

\section{Chlorinated POPs in the environment}

\subsection{OCPS}

Technical HCHs and DDTs were widely used in China from the 1950s until their production was officially banned in 1983 (Gong et al., 2007). Studies on OCPs in the Bohai and Yellow Seas started in the 1990s (Lu et al., 2007b). Occurrences of OCPs in sediments from rivers, estuaries, intertidal zones, bays, and seas have been widely investigated, especially in adjacent rivers and estuaries (Fig. 2). Overall, concentrations in sediments from rivers were higher than those from the open ocean. OCPs from rivers flowing into Bohai Bay were relatively higher (Li et al., 2013), followed by those from Jiaozhou Bay (Wang et al., 2007). In the northern Bohai Sea and its coastal area, concentrations of $\mathrm{HCH}$ and DDTs were generally less than $100 \mathrm{ng} \mathrm{g}^{-1} \mathrm{dw}$ (Gao et al., 2015; Li et al., 1998; Wang et al., 2007; Wang, 2013; Yuan et al., 2015). In coastal area of Bohai Bay, concentrations of HCHs and DDTs were generally higher and mainly exceeded $100 \mathrm{ng} \mathrm{g}^{-1} \mathrm{dw}$ (Gan, 2010; Li et al., 2013; Qin et al., 2010; Wang, 2010; Zhao et al., 2010). Increasing trend of HCHs and decreasing trend of DDTs were observed from 2004 to 2010. While in Bohai Bay, concentrations of HCHs and DDTs decreased and all those were less than $50 \mathrm{ng} \mathrm{g}^{-1} \mathrm{dw}$ (Gan, 2010; Hu et al., 2014; Liu et al., 2012; Wang, 2010; Zhang, 2009a). HCHs and DDTs generally both showed decreased trend from 2004 to 2012. In Jiaozhou Bay and its coastal area, while concentrations of HCHs and
DDTs were less than $100 \mathrm{ng} \mathrm{g}^{-1} \mathrm{dw}$ (Cao, 2008; Zhang, 2009b; Zhou et al., 2012). Concentrations of HCHs and DDTs varied greatly among areas. Relatively great concentrations were found in sediments from Haihe River (Zhao et al., 2010). The highest concentration of HCHs was detected in lower reaches of the Haihe River, with a value of $11,806 \mathrm{ng} \mathrm{g}^{-1} \mathrm{dw}$ (Li et al., 2013). DDTs in sediments were generally lower than that of $\mathrm{HCHs}$, with the highest concentration of $1417 \mathrm{ng} \mathrm{g}^{-1} \mathrm{dw}$ in coastal area of Bohai Bay (Ma et al., 2001). When comparing concentrations of residues in sediments with quality standards, $\mathrm{HCHs}$ from the most study areas were higher than probable effect level (PEL, $0.99 \mathrm{ng} \mathrm{g}^{-1} \mathrm{dw}$ ) (Feng et al., 2011), maybe posing certain harm to environment and wildlife. Most DDTs were lower than effect range median (ERM, $46.1 \mathrm{ng} \mathrm{g}^{-1}$ dw) (Feng et al., 2011), but these sites with higher than ERM would be subjected to frequently adverse biological effects, such as the Haihe River and Bohai Bay.

In South Korea, HCHs and DDTs were banned for agricultural use in 1969 under the Agro Chemicals Control Act (ACCA) (Kim and Yoon, 2014). Along the west coast of South Korea, HCHs and DDTs were widely distributed in sediments (Fig. 2) (Choi et al., 2010, 2011a, 2011b, 2014; Hong et al., 2006a, 2009; Khim et al., 1999; Koh et al., 2005; Lee et al., 2001b). Greater concentrations of $\mathrm{HCHs}$ were found in inland sediments of Lake Sihwa (0.55-10.7 $\mathrm{ng} \mathrm{g}^{-1} \mathrm{dw}$ ) (Koh et al., 2005). Concentrations of HCHs were relatively great in sediments of industrialized and urbanized regions, with some concentrations of $\mathrm{HCHs}$ exceeded the PEL. Although their production and use had mostly been banned since the late 1960s, DDTs were still found in various marine samples and were widely distributed along the coasts of South Korea. In South Korea, approximately 758 tons and 1320 tons of DDT were produced and imported from 1949 to 1971. This study found that coastal sediments of the West Sea were widely contaminated by DDTs (Fig. 2), which was the major organochlorine pesticide. Incheon Harbor was identified as an area of concern because of 


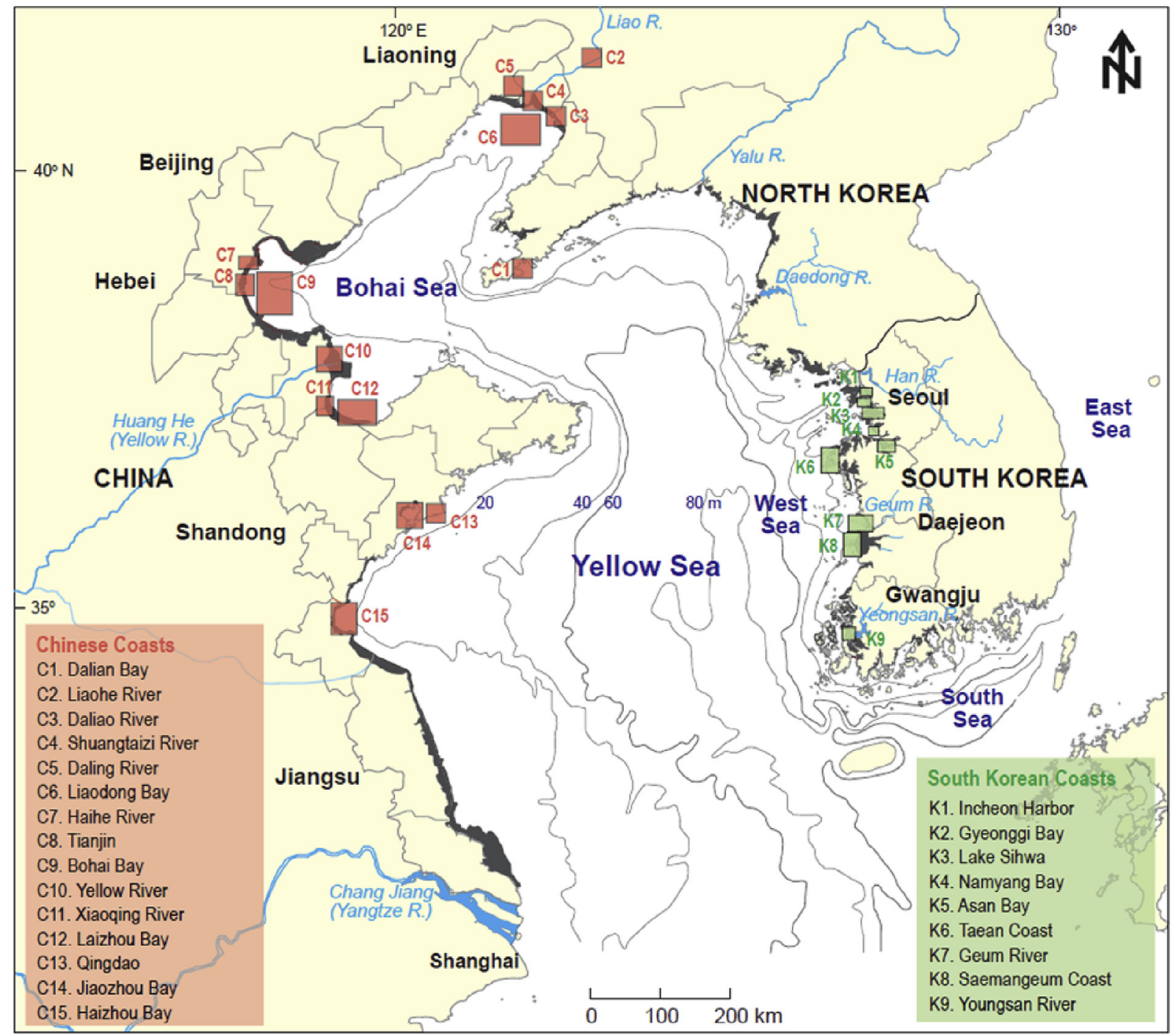

Fig. 1. Map showing the locations of the study areas along the Bohai Sea and Yellow Sea in China and South Korea.

contamination with DDTs (Lee et al., 2001b), but concentrations did not exceeded the ERM. Temporal trends of OCPs contaminations in sediments could not be evaluated due to the limited monitoring data. Overall, concentrations of OCPs in sediments of the West Sea of South Korea were generally less than those in portions of the Bohai and Yellow Seas in China.

In soils, OCPs were only investigated in Haihe River Basin, Daling River Basin, Yellow River Delta and Qingdao (Table S3) (Da, 2014; Geng, 2006; Hou et al., 2013; Li, 2010; Tao et al., 2008; Wang, 2013; Zhang, 2011). The highest concentration was measured in the Haihe River Basin, with a value of $12,549 \mathrm{ng} \mathrm{g}^{-1} \mathrm{dw}$ for $\mathrm{HCHs}$ and $2033 \mathrm{ng} \mathrm{g}^{-1} \mathrm{dw}$ for DDTs, which was mainly due to samples from the surrounding chemical industrial zone (Hou et al., 2013). Another study also reported higher OCPs in Haihe River Basin and showed that current residues of OCPs were 10-fold less than those from the 1980s (Tao et al., 2008). Based on National Environmental Quality Standards for Soils of China, soil are classified as three levels: first level (residual concentration $\leq 50 \mathrm{ng} \mathrm{g}^{-1} \mathrm{dw}$ ), second level (residual concentration from 50 to $500 \mathrm{ng} \mathrm{g}^{-1} \mathrm{dw}$ ), and third level (residual concentration from 500 to $1000 \mathrm{ng} \mathrm{g}^{-1} \mathrm{dw}$ ) for $\mathrm{HCHs}$ and DDTs (MEP China, 1995). Concentrations of HCHs and DDTs in some soils from Haihe River Basin exceeded the second level, meaning that posed risks on plants and environment in farmland, orchards and other agricultural land. Concentrations in some soils even exceeded the third level, which could not be used as land for agriculture and forestry production. HCHs and DDTs in soils from the Daling and Yellow River Basins, costal area of Bohai Sea and Qingdao were all less than $100 \mathrm{ng} \mathrm{g}^{-1} \mathrm{dw}$ (Da, 2014; Geng, 2006; Li, 2010; Wang, 2013; Zhang, 2011). Meanwhile, although studies on OCPs in soil samples along the west coast of South Korea were scarce (Kim et al., 2014), concentrations of OCPs were generally less than those in regions around the Bohai Sea (Table S3).

Studies of OCPs in riverine or marine waters were scarce and mainly focused on estuaries and bays (Table S4). Generally, concentrations of OCPs in estuaries were higher than those from bays. In the Daling, Yellow and Haihe River Estuaries, concentrations of OCPs were greatest in the Haihe River Estuary, for $\mathrm{HCHs}$ (1290-5900 $\mathrm{ng} \mathrm{L}^{-1}$ ) or DDTs (520-4840 $\mathrm{ng} \mathrm{L}^{-1}$ ), followed by those from the Daling River Estuary (Da, 2014; Wang, 2010, 2013). In Jinzhou, Bohai, Liaozhou and Jiaozhou Bays, concentrations of OCPs in marine water from Bohai Bay was the most severe (Wang, 2010; Wang et al., 2013b; Xu et al., 2007; Yao et al., 2013). Only one study reported contamination of water by OCPs in Korea, focusing on the Saemangeum Coast (Hong et al., 2006a). The results showed that contamination there was less than that in China, but similar with that in Jiaozhou Bay, which is at the same latitude. 


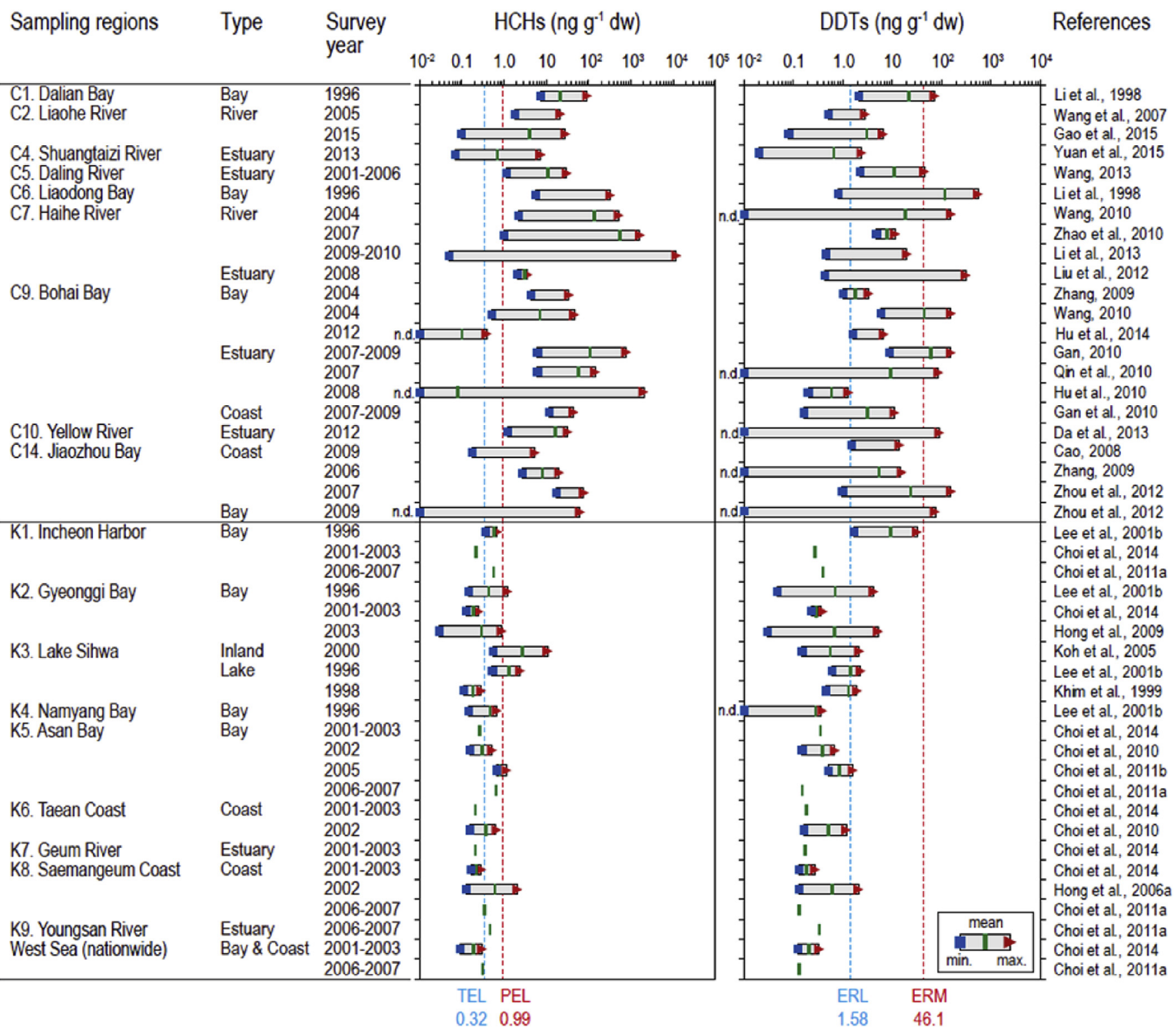

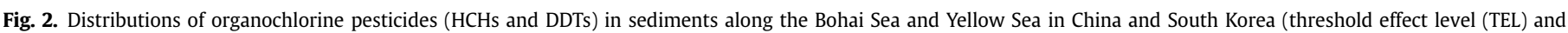
probable effect level (PEL) for HCHs from Feng et al. (2011); effect range low (ERL) and effect range median (ERM) for DDTs from Feng et al. (2011)).

\section{2. $P C B S$}

Over the last 30 years, PCBs have been detected worldwide in various environmental media. In China, approximately 10,000 tons of PCBs were produced from 1965 to 1974, after which production of PCBs was banned. A total of 9000 tons as trichlorobiphenyl and 1000 tons as pentachlorobiphenyl were produced (Xing et al. 2005). A series of studies were conducted across whole area covered in this review. In general, concentrations of PCBs in sediments were 10-fold less than those of OCPs (Fig. 3). Concentrations of PCBs in coastal areas of Liaodong Bay varied greatly. The highest concentration was detected in the Liaohe River (1075.61 $\mathrm{ng} \mathrm{g}^{-1}$ dw), flowing into Liaodong Bay (Lu, 2015; Zhang et al., 2010). Other studies reported concentrations of PCBs less than $50 \mathrm{ng} \mathrm{g}^{-1} \mathrm{dw}$ in coastal areas of Liaodong Bay (Men et al., 2014; Wang et al., 2007; Yuan et al., 2015; Zhao et al., 2011). A decreasing trend of PCBs in this area could be found from 2004 to 2012. In Bohai Bay and its coastal areas, higher concentrations of PCBs were detected in the
Haihe River, which were as great as $253 \mathrm{ng} \mathrm{g}^{-1} \mathrm{dw}$ (Gan, 2010; Hu et al., 2014; Li et al., 2013; Liu, 2010; Wang, 2010; Zhang, 2009a; Zhao et al., 2010, 2012). Concentrations of PCBs in Jiaozhou Bay and its coastal areas were similar with those from Bohai Bay and its coastal areas (Cao, 2008; Guo et al., 2011; Wang et al., 2010). In Haizhou Bay, the least concentrations of PCBs were comparable with the least concentrations from three other bays (Zhang et al., 2014). In the broader areas of the sea, sediments were less contaminated by PCBs (Duan et al., 2013; Liu et al., 2008; Ma et al., 2001; Pan et al., 2010; Wang et al., 2015; Zhang et al., 2007). PCBs in coastal areas of the Bohai and Yellow Seas were reported at an early stage of industrial development in the region. Concentrations of PCBs in Dalian, Tianjin, Qingdao, and Lianyungang, which were also the more developed cities in studied area (Ma et al., 2001), were generally less than the ERL (22.7 $\mathrm{ng} \mathrm{g}^{-1} \mathrm{dw}$ ), adverse biological effects of which would be di minimis (Zhao et al., 2010). Concentrations of PCBs from some sites in the Liaohe and Haihe Rives and Bohai, Qingdao, and Jiaozhou Bays were detected with higher 


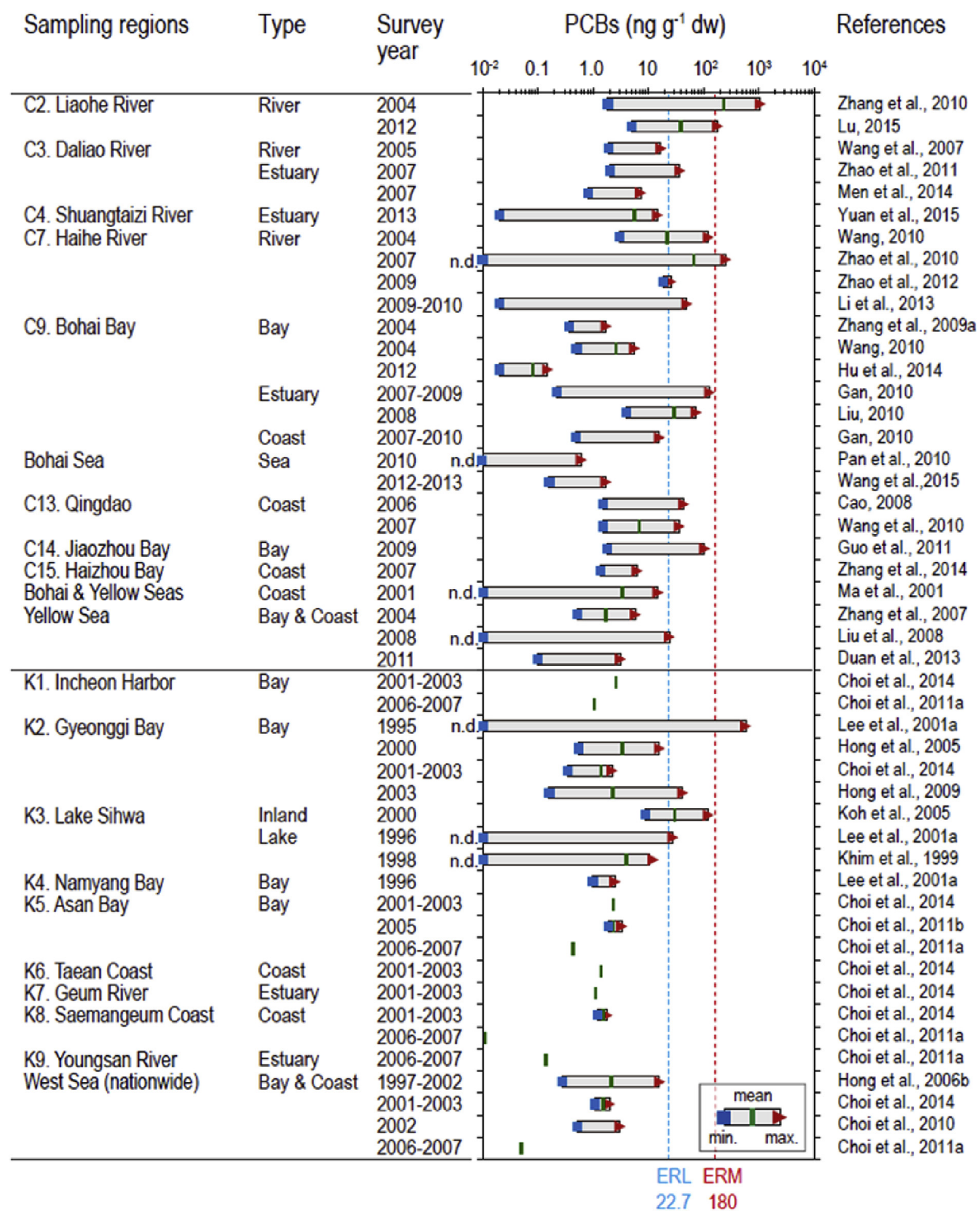

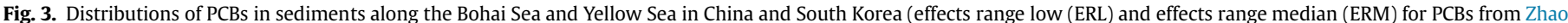
et al. (2010)).

concentrations than the ERL, and some from Liaohe River even significantly higher than the ERM ( $\left.180 \mathrm{ng} \mathrm{g}^{-1} \mathrm{dw}\right)$, which would be predicted to cause adverse biological effects.

In South Korea, despite the ban on use of PCBs as dielectric fluid in capacitors and transformers since the 1979 under the Electric Utility Act (EUA) (Kim and Yoon, 2014), PCBs were frequently detected in sediments (Fig. 3) (Choi et al., 2010, 2011a, 2011b, 2014;
Hong et al., 2005, 2006b, 2009; Koh et al., 2005; Lee et al., 2001a). Greatest concentrations of PCBs were frequently found in the greatly industrialized regions, such as Incheon Harbor $\left(1.0-580 \mathrm{ng} \mathrm{g}^{-1} \mathrm{dw}\right)$ on the west coast of South Korea, which was similar to the highest concentration detected in China which was associated with adverse effects (Lee et al., 2001a). Concentrations of PCBs in sediments from some sites exceeded the ERM (Zhao et al., 


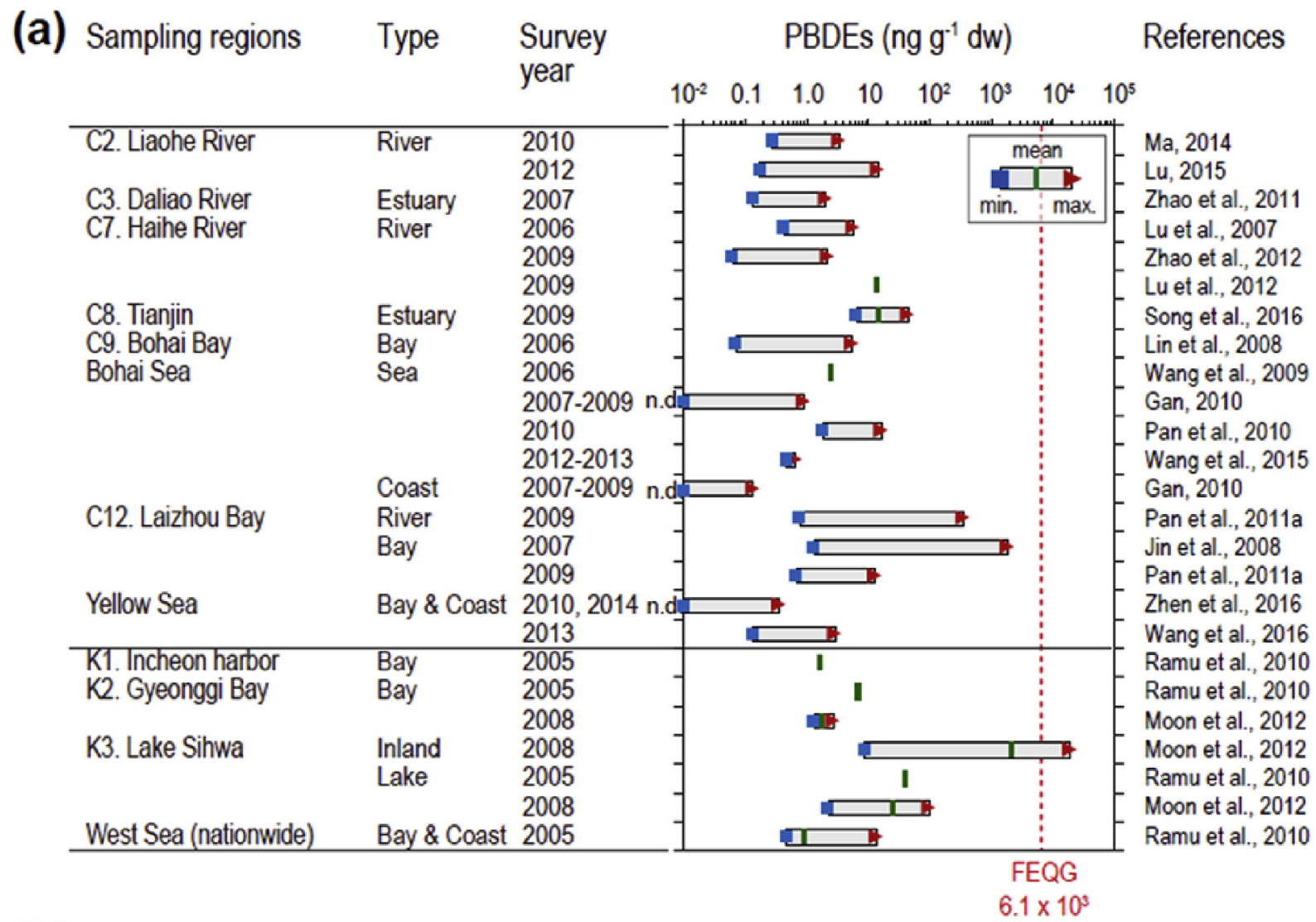

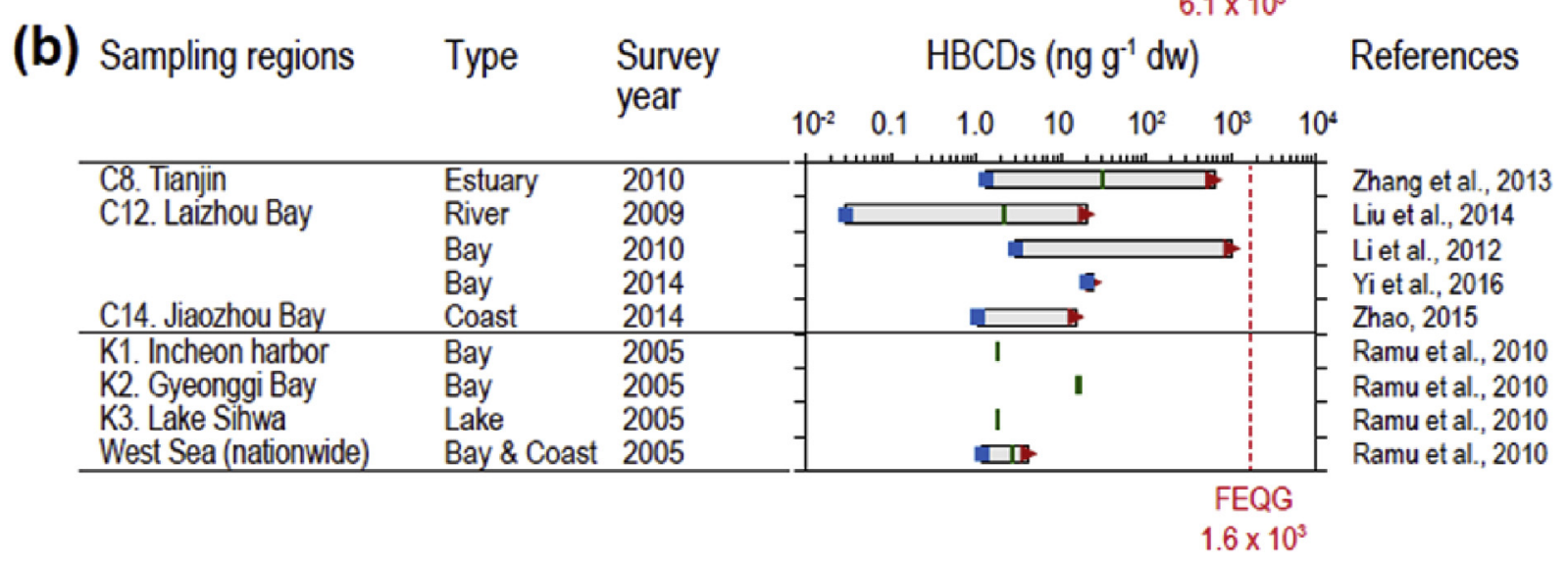

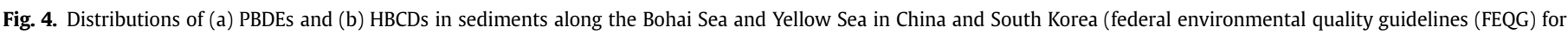
PBDEs and HBCDs from Environment Canada $(2013,2016)$ ).

2010). Temporal trends of sedimentary PCBs in Gyeonggi Bay showed slightly decreasing trend from 1995 to 2003 (Choi et al., 2014; Hong et al., 2005, 2009; Lee et al., 2001a). Overall, concentrations of PCBs in sediments were generally comparable between the west coast of South Korea and Bohai Sea regions of China.

PCBs in soils were investigated in relatively developed areas of China, such as Tianjin, Qingdao, Dalian and the Yellow River Delta (Table S5). In these four areas, the highest concentrations of PCBs were detected in Tianjin, where concentrations were as great as $373 \mathrm{ng} \mathrm{g}^{-1} \mathrm{dw}$ (Hou et al., 2013), followed by those in Yellow River Delta (Zhang, 2011). In Tianjin, Dagu Chemical Co., Ltd was recognized as the main source. In Qingdao and Dalian, concentrations of PCBs were all less than $15 \mathrm{ng} \mathrm{g}^{-1} \mathrm{dw}$, but no obvious primary source was identified (Geng, 2006; Wang et al., 2008). A study of PCBs in soils from across China was conducted in 2005, concentrations ranged from 0.14 to $1.84 \mathrm{ng} \mathrm{g}^{-1} \mathrm{dw}$ (Ren et al., 2007). Concentrations of PCBs in soils from coastal areas of the Bohai and Yellow Seas were moderate and the tri-PCB homologue was dominant, followed by di-PCB homologue. According to Environmental Quality Standards for Soils (revised draft), the second level criteria for agricultural and industrial lands are 100 and $1500 \mathrm{ng} \mathrm{g}^{-1} \mathrm{dw}$, respectively, which means that it is possible for adverse effects to occur at concentrations exceeding that concentration (MEP China, 2008). Based on this guideline, most sites could be used as agricultural land, while some could be used as other land use purposes and did not need remediation. One study reported concentrations of PCBs in soils from South Korea, which showed lesser contamination than that observed in China (Kim et al., 2016).

PCBs in river or marine waters are only investigated in the northern Bohai Sea, including the Daliao and Haihe Rivers and 


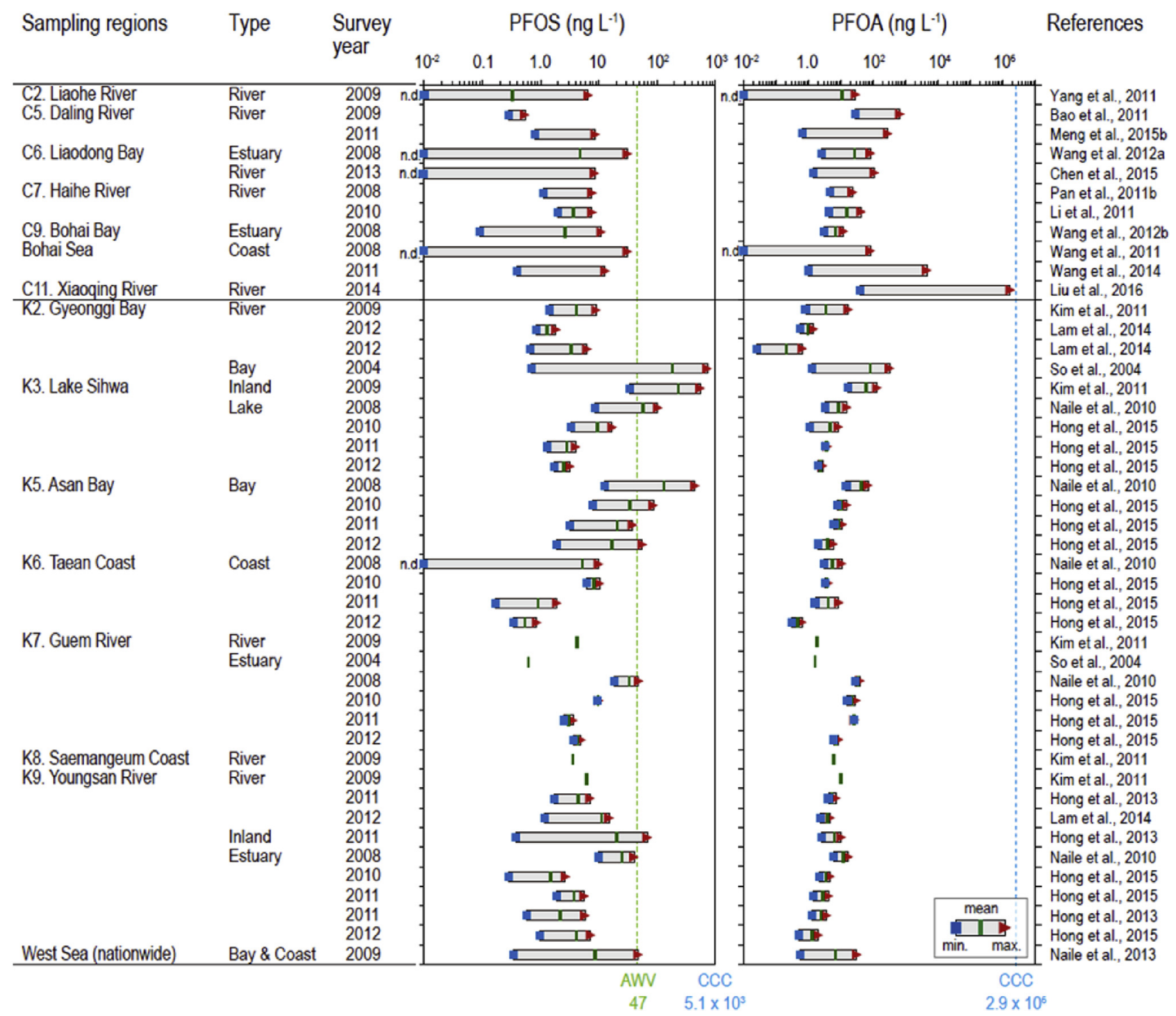

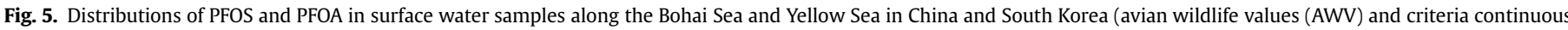
concentration (CCC) for PFOS and PFOA from Giesy et al. (2010)).

Jinzhou and Bohai Bays (Table S5). Generally, concentrations of total PCBs in water from Jinzhou Bay and the Haihe River Estuary were greater, with concentrations of 215.4-3161 $\mathrm{ng} \mathrm{\textrm {L } ^ { - 1 }}$ and 310-3110 $\mathrm{ng} \mathrm{L}^{-1}$, respectively (Wang, 2010; Yao et al., 2013). Concentrations of PCBs in water from Bohai Bay were 10-fold less than those from Jinzhou Bay and the Haihe River Estuary (Wang et al., 2013b; Wang, 2010). Concentrations of PCBs from lower reaches of the Haihe River to Bohai Bay were analyzed (Wang, 2010). Concentrations of PCBs in water from the Haihe River were significantly greater than those from Bohai Bay. The highest concentrations of PCBs were detected in the estuary. This study through continues monitoring showed that an increasing trend of detected PCBs was observed from 2004 to 2006. This result indicated a new source. Long-term air transportation and unintentional production were major sources. Concentrations of PCBs in water from the Daliao River Estuary were least (Men et al., 2014). In these areas, concentrations of PCBs in water were generally greater than were concentrations of OCPs (mainly HCHs and DDTs), which was likely due to the phase-out of HCHs and DDTs.

\section{Brominated POPs in environment}

\subsection{PBDES}

Several studies of PBDEs in sediments from areas surrounding the Bohai Sea, from the Liaohe River Basin in the north to Laizhou Bay in the south have been conducted (Fig. 4a). The most severely polluted area was Laizhou Bay due to manufacture of PBDEs and Bohai Bay due to use and disposal of electronic products. The greatest concentration of PBDEs was detected in the Bailong River, Laizhou Bay, with concentrations as great as $1800 \mathrm{ng} \mathrm{g}^{-1} \mathrm{dw}$ (Jin et al., 2008; Pan et al., 2011a). In areas adjacent to Bohai Bay, rivers flowing into the Bohai Sea were most heavily contaminated by PBDEs, with the highest concentration of $42.79 \mathrm{ng} \mathrm{g}^{-1} \mathrm{dw}$ ( Gan, 2010; Lu et al., 2007a, 2012; Pan et al., 2010; Song et al., 2016; Zhao et al., 2012). Three studies were conducted to investigate PBDEs in sediment in the Liaohe River Basin. Similar concentrations were detected among the studies with concentrations less than $15 \mathrm{ng} \mathrm{g}^{-1}$ dw (Lu, 2015; Ma, 2014; Zhao et al., 2011). In addition, less 
concentrations of PBDEs were detected in marine sediments from coastal areas of the Bohai Sea (Lin et al., 2008; Wang et al., 2009). Bohai and Laizhou Bays were more polluted than other areas of the Bohai Sea. Only one study was carried out to investigate concentrations of PBDEs in marine sediments from the Yellow Sea and similar concentrations were detected with those from Bohai Sea (Wang et al., 2016). Principal component analysis (PCA) reveled that PBDEs in the Yellow Sea were mainly from the continental runoff (69\%) and atmospheric deposition (31\%). No concentrations of PBDEs exceeded the sediment quality guideline (6143 $\mathrm{ng} \mathrm{g}^{-1}$ dw), meaning no potential risks (Environment Canada, 2013).

Contamination of sediments by PBDEs was widespread along the Korean coast (Moon et al., 2012; Ramu et al., 2010). Results of previous studies revealed that greatest concentrations of PBDEs in sediments were observed in creeks flowing into Lake Sihwa (8.5-18,700 ng g ${ }^{-1} \mathrm{dw}$ ) (Moon et al., 2012) (Fig. 4a). In particular, concentrations of PBDEs detected in the Lake Sihwa near industrial complexes exceeded the federal environmental quality guidelines (FEQG) (Environment Canada, 2013) and were greatest compared with worldwide values. Although PBDEs in Korean sediments were less studied and thus temporal distribution trends could not be evaluated, significant reductions in concentrations of PBDEs in sediments were observed during recent years. This reduction seems to be the result of a recent ban on the use and production of commercial PBDEs in Korea. More monitoring of PBDEs and novel brominated flame retardants or other non-brominated replacements in coastal environments is needed.

There were large differences in concentrations of PBDEs in soils from coastal areas of the Bohai Sea (Table S6). The most seriously contaminated areas were in the vicinity of sites where PBDEs were manufactured or used for making electronics or where electronic devices were dismantled. Several studies that have investigated PBDEs in soils around manufacturing sites of Laizhou Bay revealed that BDE-209 was the predominant congener (Deng et al., 2016; Jin et al., 2011; Liu et al., 2014a; Li et al., 2015). In these studies, the greatest concentration of PBDEs was 226,906 $\mathrm{ng} \mathrm{g}^{-1} \mathrm{dw}$. At sites where electronics were dismantled, such as Tianjin, concentrations of PBDEs ranged from 1.34 to $343.88 \mathrm{ng} \mathrm{g}^{-1} \mathrm{dw}$ (Liu, 2013). A series of studies investigated PBDEs in soils from various provinces on the Bohai Rim (Liu, 2013). Soils from north China were collected from Beijing, Tianjin, Shandong, Hebei and Shanxi. Concentrations of PBDEs were between 0.01 and $948.84 \mathrm{ng} \mathrm{g}^{-1} \mathrm{dw}$. There was an increasing trend from inland to coast and the most severe polluted areas were distributed in Shandong, especially Laizhou Bay (Chen et al., 2012; Yuan, 2013). Concentrations of PBDEs in soils from the west coast of South Korea were less than those from near the Bohai and Yellow Seas of China (Kim et al., 2014).

\section{2. $H B C D s$}

Based on regulatory restrictions on uses of PBDE formulations, usage of $H B C D$ has increased during the past decade with a concomitant increase in concentrations of HBCDs in environmental media. However, information on concentrations of HBCDs in environment in Bohai and Yellow Sea regions in both China and South Korea was scarce. Some studies investigated concentrations of HBCDs in sediment and soils (Fig. 4b and Table S7). Generally, concentrations of HBCDs were not high, except those in samples from manufacturing sites near Laizhou Bay. Laizhou Bay area is the center of the brominated chemical industry in China, with many BFR manufacturing facilities located in the industrial park of Weifang city near Laizhou Bay (Li et al., 2012). HBCDs in soils and sediments from on-site and off-site at HBCDs production and processing plants were investigated (Yi et al., 2016). Concentrations of HBCDs in soils collected on-site and off-site were
96.1-560.4 $\mathrm{ng} \mathrm{g}^{-1} \mathrm{dw}$ and $0.11-31.1 \mathrm{ng} \mathrm{g}^{-1} \mathrm{dw}$, respectively. Two samples of sediments were also collected around plants, and concentrations were $20.4 \mathrm{ng} \mathrm{g}^{-1} \mathrm{dw}$ and $24.2 \mathrm{ng} \mathrm{g}^{-1} \mathrm{dw}$, respectively. Another study reported relatively higher concentrations of HBCDs in environment near manufacturing facilities in Laizhou Bay area (Liu et al., 2012). Concentrations in soils and sediment were 0.88-6901 $\mathrm{ng} \mathrm{g}^{-1} \mathrm{dw}$ and 2.93-1029 $\mathrm{ng} \mathrm{g}^{-1} \mathrm{dw}$, respectively. Relatively greater concentrations of HBCDs were detected in sediments from rivers and harbor of Tianjin, with values of 1.35-634 $\mathrm{ng} \mathrm{g}^{-1} \mathrm{dw}$ (Zhang et al., 2013b). In these studies areas, $\gamma$ HBCD was predominant, which was consistent with the pattern of distributions of diastereomer in industrial products.

HBCDs in soils from coastal cities along the Bohai and Yellow Seas were reported (Zhang et al., 2016). Concentrations of HBCDs ranged from $0.12 \mathrm{ng} \mathrm{g}^{-1} \mathrm{dw}$ to $363 \mathrm{ng} \mathrm{g}^{-1} \mathrm{dw}$. Generally, soils from coastal cities along Bohai Sea were more seriously polluted than those along Yellow Sea. Among all 21 cities, the highest mean concentrations of HBCDs were $34.6 \mathrm{ng} \mathrm{g}^{-1} \mathrm{dw}$ in Weifang, $12.3 \mathrm{ng} \mathrm{g}^{-1} \mathrm{dw}$ in Cangzhou and $11.1 \mathrm{ng} \mathrm{g}^{-1} \mathrm{dw}$ in Tianjin. Mean concentrations from the other 18 cities were all less than $10 \mathrm{ng} / \mathrm{g}$ $\mathrm{dw}$ from other 18 cities. In addition, some studies were carried out in the Yellow River Delta, rivers flowing into Laihou Bay and Jiaozhou Bay area, and less HBCDs were detected (Liu et al., 2014b; Yuan, 2013; Zhao, 2015). The highest concentration of HBCDs did not exceed the FEQG for sediment ( $1600 \mathrm{ng} \mathrm{g}^{-1} \mathrm{dw}$ ) but was close (Environment Canada, 2016). Therefore, with continuous production and accumulation of HBCDs in sediment, it will likely cause harm near these sites of production. Worldwide, including in the South Korea, few studies of occurrences of HBCDs have been reported (Fig. 4b). Results indicated that relatively great concentrations of HBCDs were found in Gyeonggi Bay near industrial complexes and harbors (Ramu et al., 2010). However, detected HBCDs concentrations in sediments did not exceeded the FEQG (Environment Canada, 2016). More complementary studies on sources, distributions, and potential toxic effects on marine organisms of emerging contaminants HBCDs are needed for assessment and management.

\section{Fluorinated POPs in environment}

PFASs were widely distributed in water of rivers and marine environments of the Bohai and Yellow Seas due to their solubility in water and negligible vapor pressures, when dissolved in water (Fig. 5, Tables S8 and S9). There were abundant studies on PFASs in water and sediment of rivers of the Bohai Rim. Concentrations of PFOS and PFOA in water from the northern Bohai coastal areas ranged from n.d. to 30.9 and n.d. $-81.7 \mathrm{ng} \mathrm{L}^{-1}$, respectively (Wang et al., 2011), while those in south Bohai costal area were $0.40-12.78$ and $0.96-4534 \mathrm{ng} \mathrm{L}^{-1}$, respectively (Wang et al., 2014). Corresponding concentrations of PFASs in sediments were also reported. Concentrations of PFOS and PFOA in sediment from the northern Bohai coastal areas were n.d.- 1.97 and n.d. $-0.54 \mathrm{ng} \mathrm{g}^{-1}$ dw, respectively (Wang et al., 2011), while those in southern Bohai coastal areas were $0.03-0.44$ and $0.005-29.02 \mathrm{ng} \mathrm{g}^{-1} \mathrm{dw}$, respectively (Zhu et al., 2014). The greatest concentration was observed in the Xiaoqing River, which was likely due to the presence of local fluorine chemical industries. Pollution of PFASs in water and sediment of Liaodong Bay basin was investigated, and results showed that PFASs in the Daling River were relatively great (Chen et al., 2015).

Occurrences and fates of PFASs in marine sediments from the Bohai and Yellow Seas were reported (Gao et al., 2014). In the Bohai Sea, concentrations of PFOS and PFOA were n.d.-0.15 and $0.06-2.70 \mathrm{ng} \mathrm{g}^{-1} \mathrm{dw}$, among which relatively high concentrations were found near Liaodong Bay. In the Yellow Sea, concentrations of 
PFOS and PFOA were n.d. -0.40 and nd $-1.52 \mathrm{ng} \mathrm{g}^{-1} \mathrm{dw}$, which was due to fluorine chemical plants in the Daling and Xiaoqing River basins. Concentrations of PFASs were investigated in the surroundings of fluorine chemical plants in the Daling River basin (Bao et al., 2011). Concentrations of PFOS and PFOA in water from streams in the Daling River basin were $0.28-0.54$ and 27.2-668 $\mathrm{ng} \mathrm{L}^{-1}$, respectively, while those in sediment were n.d. and $0.18-18 \mathrm{ng} \mathrm{g}^{-1} \mathrm{dw}$, respectively. Sediment cores and overlying water were also collected to investigate pollution history in Daling River basin (Meng et al., 2015b). Concentrations of PFOS and PFOA in surface water were $0.80-8.7$ and $0.63-284 \mathrm{ng} \mathrm{L}^{-1}$, respectively. Concentrations of PFOA in water from the Xiaoqing River basin ranged from 38.6 to $1,707,290 \mathrm{ng} \mathrm{L}^{-1}$ (Liu et al., 2016). The greatest concentrations of PFASs in sediment were detected in the Xiaoqing River, of which PFOA was dominant and its concentrations were between 3.86 and $456.20 \mathrm{ng} \mathrm{g}^{-1} \mathrm{dw}$ (Sun et al., 2016). In addition, studies in the Liaohe, Haihe and Yellow Rivers were also carried out (Li et al., 2011; Pan et al., 2011b; Wang et al., 2012a, 2012b; Yang et al., 2011; Zhao et al., 2013). Since there was no obvious production of PFASs and related products, PFOS and PFOA in water were less than $100 \mathrm{ng} \mathrm{L}^{-1}$ and those in sediment were less than $10 \mathrm{ng} \mathrm{g}^{-1} \mathrm{dw}$ in these rivers. It was noted that concentrations of PFOA in China were generally higher than that of PFOS. Concentrations of both PFOS and PFOA in water did not exceed water quality guidelines, avian wildlife values (AWV) or criteria continuous concentration (CCC), which indicates that there would be no harm to wildlife or aquatic organisms expected (Giesy et al., 2010).

In recent years, on the west coast of South Korea, concentrations of waterborne PFASs have generally decreased (Hong et al., 2015; Naile et al., 2010, 2013). Distributions of concentrations of PFASs indicated that they were greater in freshwater than they were in seawater, which suggested that PFASs originated from point sources of surrounding inland areas rather than from non-point sources (Naile et al., 2013). Greatest concentrations of PFOS and PFOA in water were found in Gyeonggi Bay, followed by Lake Sihwa, and Lake Asan (Fig. 5) (Hong et al., 2013, 2015; Kim et al., 2011; Lam et al., 2014; Naile et al., 2010; So et al., 2004). Concentrations of PFOA in some water samples from these sites exceeded the AWV and would have been expected to cause some adverse effects. Temporal trends in concentrations of PFASs in water samples indicated that concentrations have decreased since 2008 (Hong et al., 2013; Naile et al., 2010, 2013). Relative contributions of PFOS decreased, while those of shorter-chain PFASs such as PFBA have increased in recent years, which indicated that recent global restrictions on uses of some PFASs have resulted in less production and subsequent releases to the environment. In 2010, the government of South Korea designated PFASs (PFOS and its salts and PFOSF) as "restricted chemicals" in the "Persistent Organic Pollutants Control Act (PCA)". The PCA covers the regulations of commercial use, waste management, and emission control, etc. (Kim and Yoon, 2014). Overall, concentrations of PFOS in water were generally greater in the Bohai and Yellow Sea regions of China than those from the west coast of South Korea. Concentrations of PFOA in Chinese coasts were greater than those of South Korea. Some sediment samples were collected from coastal areas of the West Sea, Han River and Yeongsan River (Lam et al., 2014; Naile et al., 2013). In general, concentrations of PFOS and PFOA from these rivers were small. Concentrations of PFOA and PFOS from coastal areas of the West Sea were similar to those in China, except PFOA, concentrations of which were greater at some manufacturing sites, such as watershed of the Xiaoqing River in China.

Studies on PFASs in soils were scarce, but almost cover whole coastal areas of Bohai Sea and West Sea of South Korea (Table S9). Generally, concentrations of PFOS and PFOA in soils were small and most were less than $10 \mathrm{ng} \mathrm{g}^{-1} \mathrm{dw}$ (Meng et al., 2015a; Wang et al., 2011, 2012b). Relatively more studies have been conducted in the area surrounding Liaodong, Bohai, and Laizhou Bays. Relatively greater concentrations were detected in these three areas, which was likely due to production of PFASs (Liaodong Bay and Laizhou Bay) and numerous industrial applications (Bohai Bay) (Pan et al., 2011b; Wang et al., 2012b, 2013a). In South Korea, concentrations of PFOA and PFOS in soils from coastal areas of the West Sea were greater than those from inland regions (Lam et al., 2014; Naile et al., 2013).

\section{Future research direction}

In the present review, spatial distributions and potential risks of several POPs in environmental media along the Bohai and Yellow Seas were summarized. Results of data review suggested that sources of different POPs were independent and some hotspot areas with greater production of certain chemicals were identified (Table 2). Bohai Bay and Haihe River in China and Gyeonggi Bay and Lake Sihwa in South Korea were found to be the hot spot areas for traditional POPs pollution along the Bohai Sea and Yellow Sea regions. Meanwhile, new POPs such as PBDEs, HBCDs, and PFASs were greatly polluted in some regions, for example, Laizhou Bay, Tianjin, Xiaoqing River, and Asan Bay. Patterns of POPs pollution (e.g., chemicals of concerns) were distinguished between China and South Korea. Temporal trends of sedimentary POPs were found to decrease in recent years that seemed to be associated with chemical controls and regulations, mainly for banned OCPs and PCBs, and PFASs in South Korea. Studies on new POPs such as PBDEs and HBCDs in multimedia samples were still limited. In addition, environmental quality guidelines of POPs for protection of the coastal ecosystem have not been established in both China and South Korea. We suggest that the future research directions of POPs based on the current understandings and limitations, include: 1)

Table 2

Summary of results of the review, including key sources of POPs and hotspot areas along the Bohai and Yellow Seas in China and South Korea.

\begin{tabular}{|c|c|c|c|c|c|c|c|}
\hline \multirow[t]{2}{*}{ POPs } & \multirow[t]{2}{*}{ General distribution } & \multicolumn{3}{|c|}{ Areas of concern in Chinese Coasts } & \multicolumn{3}{|c|}{ Areas of concern in Korean Coasts } \\
\hline & & $1 \mathrm{st}$ & 2nd & 3rd & $1 \mathrm{st}$ & 2nd & $3 r d$ \\
\hline \multicolumn{8}{|c|}{ Chlorinated POPs } \\
\hline OCPs & China $\gg$ Korea & C7. Haihe River & C9. Bohai Bay & C14. Jiaozhou Bay & K1. Incheon Harbor & K2. Gyeonggi Bay & K3. Lake Sihwa \\
\hline PCBs & China Korea & C2. Liaohe River & C7. Haihe River & C9. Bohai Bay & K2. Gyeonggi Bay & K3. Lake Sihwa & \\
\hline \multicolumn{8}{|c|}{ Brominated POPs } \\
\hline PBDEs & China $<$ Korea & C12. Laizhou Bay & C8. Tianjin & C9. Bohai Bay & K3. Lake Sihwa & K2. Gyeonggi Bay & \\
\hline HBCDs & China $>$ Korea & C12. Laizhou Bay & C8. Tianjin & & & & \\
\hline \multicolumn{8}{|c|}{ Fluorinated POPS } \\
\hline PFOS & China $<$ Korea & C9. Bohai Bay & C6. Liaodong Bay & & K2. Gyeonggi Bay & K3. Lake Sihwa & K5. Asan Bay \\
\hline PFOA & China $>$ Korea & C11. Xiaoqing River & C9. Bohai Bay & & K2. Gyeonggi Bay & K3. Lake Sihwa & K5. Asan Bay \\
\hline
\end{tabular}


systematic monitoring of new POPs for baseline data; 2) establishment of sediment quality guidelines; 3 ) monitoring of alternatives for POPs; 4) identification of unknown toxic chemicals (nontargeted screening); 4) determination of ecotoxicological effects; 6 ) determination of mixture effects of POPs and other pollutants; and 7) approach of multiple lines of evidence for accurate risk assessment. Overall, the present review will guide identification for areas of concerns and prioritization of research on POPs pollution assessment and management practices in both China and South Korea.

\section{Acknowledgements}

This study was supported by the National Natural Science Foundation of China under Grant No. 41571478, 414201040045, and the National Water Pollution Control and Treatment Science and Technology Major Project with Grant No. 2015ZX07203-005. This work was also supported by the projects entitled "Oil Spill Environmental Impact Assessment and Environmental Restoration" and "Development of Integrated Estuarine Management System" funded by the Ministry of Oceans and Fisheries, Korea given to Prof. JSK. JPG was supported by the Canada Research Chair program, and the Einstein Professor Program of the Chinese Academy of Sciences.

\section{Appendix A. Supplementary data}

Supplementary data related to this article can be found at http:// dx.doi.org/10.1016/j.chemosphere.2016.11.108.

\section{References}

Bao, J., Liu, W., Liu, L., Jin, Y., Dai, J., Ran, X., Zhang, Z., Tsuda, S., 2011. Perfluorinated compounds in the environment and the blood of residents living near fluorochemical plants in Fuxin, China. Environ. Sci. Technol. 45, 8075-8080.

Canada Environment, 2013. Federal Environmental Quality Guidelines for Polybrominated Diphenyl Ethers (PBDEs). http://www.ec.gc.ca/ese-ees/default.asp? lang=En\&n=05DF7A37 -1 .

Canada Environment, 2016. Federal Environmental Quality Guidelines for Hexabromocyclododecane (HBCD). http://www.ec.gc.ca/ese-ees/default.asp? lang $=$ En $\& n=8$ BA57E1C -1 .

Cao, F., 2008. Distribution and Source Identification on the Persistent Organic Pollutants in the Surface Sediments from Qingdao Coastal Areas (In Chinese). Ocean University of China.

Chen, C., Zhao, H., Chen, J., Qiao, X., Xie, Q., Zhang, Y., 2012. Polybrominated diphenyl ethers in soils of the modern Yellow River Delta, China: occurrence, distribution and inventory. Chemosphere 88, 791-797.

Chen, H., Zhang, C., Han, J., Sun, R., Kong, X., Wang, X., He, X., 2015. Levels and spatial distribution of perfluoroalkyl substances in China Liaodong Bay basin with concentrated fluorine industry parks. Mar. Pollut. Bull. 101, 965-971.

Choi, H.G., Moon, H.B., Choi, M., Yu, J., 2011a. Monitoring of organic contaminants in sediments from the Korean coast: spatial distribution and temporal trends (2001-2007). Mar. Pollut. Bull. 62, 1352-1361.

Choi, J.Y., Lee, S.G., Bang, J.H., Yang, D.B., Hong, G.H., Shin, K.H., 2011b. On the distribution of PCBs and organochlorine pesticides in fish and sediment of the Asan Bay. Ocean Polar Res. 33, 45-53.

Choi, J.Y., Yang, D.B., Hong, G.H., 2010. Bioaccumulation of polychlorinated biphenyls (PCBs) and organochlorine pesticides in manila clams (Ruditapes philippinarum) collected from the mid-western coast of Korea. Ocean Polar Res. 32, 237-245.

Choi, J.Y., Yang, D.B., Hong, G.H., Shin, K.H., 2014. Distribution and bioaccumulation of polychlorinated biphenyls and organochlorine pesticides residues in sediments and Manila clams (Ruditapes philippinarum) from along the Mid-Western coast of Korea. Mar. Pollut. Bull. 85, 672-678.

Da, C., 2014. Studies on Environmental Geochemistry Behaviors of Organochlorine Pesticides in Environmental Mediums from the Yellow River Estuary (In Chinese). University of Science and Technology of China.

Deng, C., Chen, Y., Li, J., Li, Y., Li, H., 2016. Environmental pollution of polybrominated diphenyl ethers from industrial plants in China: a preliminary investigation. Environ. Sci. Pollut. Res. 23, 7012-7021.

Duan, X., Li, Y., Li, X., Zhang, D., Li, M., 2013. Polychlorinated biphenyls in sediments of the Yellow Sea: distribution, source identification and flux estimation. Mar Pollut. Bull. 76, 283-290.

Erickson, M.D., Kaley, R.G., 2011. Applications of polychlorinated biphenyls. Environ. Sci. Pollut. Res. 18, 135-151.

Feng, J.L., Zhai, M.X., Liu, Q., Sun, J.H., Guo, J.J., 2011. Residues of organochlorine pesticides (OCPs) in upper reach of the Huaihe River, East China. Ecotoxicol. Environ. Saf. 74, 2252-2259.

Gan, Z.F., 2010. Preliminary Study on Environmental Behavior of Typical Persistent Organic Pollutants in the West Bank of Bohai Bay (In Chinese). Hebei University. Gao, L.R., Xia, D., Tian, H.Z., Zhang, H.J., Liu, L.D., Wang, Y.W., 2015. Concentrations and distributions of 18 organochlorine pesticides listed in the Stockholm Convention in surface sediments from the Liaohe River basin, China. J. Environ. Sci. Health Part B Pesticides Food Contam. Agric. Wastes 50, 322-330.

Gao, Y., Fu, J., Zeng, L., Li, A., Li, H., Zhu, N., Liu, R., Liu, A., Wang, Y., Jiang, G., 2014. Occurrence and fate of perfluoroalkyl substances in marine sediments from the Chinese Bohai Sea, Yellow Sea, and East China Sea. Environ. Pollut. 194, 60-68.

Geng, C.Z., 2006. Studies on Chlorinated Organie Pollutants in Soils and TSP in Oingdao Region (In Chinese). Oingdao University.

Giesy, J.P., Naile, J.E., Khim, J.S., Jones, P.D., Newsted, J.L., 2010. Aquatic toxicology of perfluorinated chemicals. Rev. Environ. Contam. Toxicol. 202, 1-52.

Gong, X.Y., Qi, S.H., Wang, Y.X., Julia, E.B., Lv, C.L., 2007. Historical contamination and sources of organochlorine pesticides in sediment cores from Quanzhou Bay, Southeast China. Mar. Pollut. Bull. 54, 1434-1440.

Guo, J., Yin, Y., Zheng, L., Yu, W., Zhao, H., Yang, D., 2011. The distribution and risk assessment of polychlorinated biphenyl in surface sediments in estuaries of Jiaozhou Bay,China (in Chinese). J. Agro Environ. Sci. 30, 965-972.

Hong, S., Khim, J.S., Naile, J.E., Park, J., Kwon, B.O., Wang, T., Lu, Y., Shim, W.J., Jones, P.D., Giesy, J.P., 2012. AhR-mediated potency of sediments and soils in estuarine and coastal areas of the Yellow Sea region: a comparison between Korea and China. Environ. Pollut. 171, 216-225.

Hong, S., Khim, J.S., Park, J., Kim, M., Kim, W.K., Jung, J., Hyun, S., Kim, J.G., Lee, H., Choi, H.J., 2013. In situ fate and partitioning of waterborne perfluoroalkyl acids (PFAAs) in the Youngsan and Nakdong River Estuaries of South Korea. Sci. Total Environ. 445, 136-145.

Hong, S., Khim, J.S., Wang, T. Naile, J.E., Park, J., Kwon, B.O., Song, S.J., Ryu, J., Codling, G., Jones, P.D., 2015. Bioaccumulation characteristics of perfluoroalkyl acids (PFAAs) in coastal organisms from the west coast of South Korea. Chemosphere 129, 157-163.

Hong, S., Lee, J., Lee, C., Yoon, S.J. Jeon, S., Kwon, B.-O., Lee, J-H., Giesy, J.P. Khim, J.S. 2016. Are styrene oligomers in coastal sediments of an industrial area aryl hydrocarbon-receptor agonists? Environ. Pollut. 213, 913-921.

Hong, S., Yim, U., Shim, W., Li, D., Oh, J., 2006b. Nationwide monitoring of polychlorinated biphenyls and organochlorine pesticides in sediments from coastal environment of Korea. Chemosphere 64, 1479-1488.

Hong, S.H., Kannan, N., Yim, U.H., Li, D., Kim, M., Shim, W.J., 2009. Assessment of sediment contamination by persistent organic pollutants in Gyeonggi Bay, Korea. Toxicol. Environ. Health Sci. 1, 56-63.

Hong, S.H., Shim, W.J., Li, D.H., Yim, U.H., Oh, J.R., Kim, E.S., 2006a. Contamination status and characteristics of persistent organochlorine pesticides in the Saemangeum environment. Ocean Polar Res. 28, 317-329.

Hong, S.H., Yim, U.H., Shim, W.J., Oh, J.R., 2005. Congener-specific survey for polychlorinated biphenyls in sediments of industrialized bays in Korea: regional characteristics and pollution sources. Environ. Sci. Technol. 39, 7380-7388.

Hou, H., Zhao, L., Zhang, J., Xu, Y.F., Yan, Z.G., Bai, L.P., Li, F.S., 2013. Organochlorine pesticides and polychlorinated biphenyls in soils surrounding the Tanggu Chemical industrial District of Tianjin, China. Environ. Sci. Pollut. Res. 20, 3366-3380.

Hu, S.Q., Tang, L.L., Ma, S.M., Wang, H.Y., 2014. Composition, source and risk assessment of the organic pollutants in the surface sediments from the Bohai Gulf (in Chinese), Geophys, Geochem. Explor. 38, 309-317.

Jin, J., Liu, W., Wang, Y., Tang, X.Y., 2008. Levels and distribution of polybrominated diphenyl ethers in plant, shellfish and sediment samples from Laizhou Bay in China. Chemosphere 71, 1043-1050.

Jin, J., Wang, Y., Liu, W., Yang, C., Hu, J., Cui, J., 2011. Polybrominated diphenyl ethers in atmosphere and soil of a production area in China: levels and partitioning. J. Environ. Sci. 23, 427-433.

Jones, K.C., De Voogt, P., 1999. Persistent organic pollutants (POPs): state of the science. Environ. Pollut. 100, 209-221.

Kannan, K., 2011. Perfluoroalkyl and polyfluoroalkyl substances: current and future perspectives. Environ. Chem. 8, 333-338.

Kelly, B.C., Ikonomou, M.G., Blair, J.D., Morin, A.E., Gobas, F.A., 2007. Food web-specific biomagnification of persistent organic pollutants. Science 317, 236-239.

Khim, J.S., Villeneuve, D.L., Kannan, K., Lee, K.T., Snyder, S.A., Koh, C.H., Giesy, J.P. 1999. Alkylphenols, polycyclic aromatic hydrocarbons, and organochlorines in sediment from Lake Shihwa, Korea: instrumental and bioanalytical characterization. Environ. Toxicol. Chem. 18, 2424-2432.

Kim, E.J., Park, Y.M., Park, J.E., Kim, J.G., 2014. Distributions of new Stockholm convention POPs in soils across South Korea. Sci. Total Environ. 476, 327-335.

Kim, L., Jeon, J.W., Lee, Y.S., Jeon, H.J., Park, B.J., Lee, H.S., Choi, S.D., Lee, S.E., 2016. Monitoring and risk assessment of polychlorinated biphenyls (PCBs) in agricultural soil collected in the vicinity of an industrialized area. Appl. Biol. Chem. $1-5$.

Kim, S.K., Kho, Y.L., Shoeib, M., Kim, K.S., Kim, K.R., Park, J.E., Shin, Y.S., 2011 Occurrence of perfluorooctanoate and perfluorooctanesulfonate in the Korean water system: implication to water intake exposure. Environ. Pollut. 159, 1167-1173.

Kim, S.K., Yoon, J., 2014. Chronogical trends of emission, environmental level and human exposure of POPs over the last 10 years $(1999-2010)$ in Korea: implication to science and policy. Sci. Total Environ. 470-471, 1346-1361. 
Koh, C.H., Khim, J.S., Villeneuve, D.L., Kannan, K., Johnson, B.G., Giesy, J.P., 2005. Instrumental and bioanalytical measures of dioxin-like and estrogenic compounds and activities associated with sediment from the Korean coast. Ecotoxicol. Environ. Saf. 61, 366-379.

La Guardia, M.J., Hale, R.C., Harvey, E., 2006. Detailed polybrominated diphenyl ether (PBDE) congener composition of the widely used penta-, octa-, and decaPBDE technical flame-retardant mixtures. Environ. Sci. Technol. 40, 6247-6254.

Lam, N.H., Cho, C.R., Lee, J.S., Soh, H.Y., Lee, B.C., Lee, J.A., Tatarozako, N., Sasaki, K., Saito, N., Iwabuchi, K., 2014. Perfluorinated alkyl substances in water, sediment, plankton and fish from Korean rivers and lakes: a nationwide survey. Sci. Total Environ. 491, 154-162.

Lee, K.T., Tanabe, S., Koh, C.H., 2001a. Contamination of polychlorinated biphenyls (PCBs) in sediments from Kyeonggi Bay and nearby areas, Korea. Mar. Pollut. Bull. 42, 273-279.

Lee, K., Tanabe, S., Koh, C., 2001b. Distribution of organochlorine pesticides in sediments from Kyeonggi Bay and nearby areas, Korea. Environ. Pollut. 114, 207-213.

Li, C., Zheng, M., Gao, L., Zhang, B., Liu, L., Xiao, K., 2013. Levels and distribution of $\mathrm{PCDD} / \mathrm{Fs}$, dl-PCBs, and organochlorine pesticides in sediments from the lower reaches of the Haihe River basin, China. Environ. Monit. Assess. 185, 1175-1187.

Li, F., Sun, H., Hao, Z., He, N., Zhao, L., Zhang, T., Sun, T., 2011. Perfluorinated compounds in Haihe River and Dagu Drainage Canal in Tianjin, China. Chemosphere 84, 265-271.

Li, H., Fu, Y.Z., Zhou, C.G., Xu, H.Z., 1998. Distribution characteristics of organic chlorine pesticide and PCB in the surface sediments in Dalian Bay and Jinzhou Bay (in Chinese). Mar. Environ. Sci. 17, 73-76.

Li, H.H., Zhang, Q.H., Wang, P., Li, Y.M., Lv, J.X., Chen, W.H., Geng, D.W., Wang, Y.W., Wang, T., Jiang, G.B., 2012. Levels and distribution of hexabromocyclododecane (HBCD) in environmental samples near manufacturing facilities in Laizhou Bay area, East China. J. Environ. Monit. 14, 2591-2597.

Li, S.M., 2010. Pollution Characteristics of Organochlorine Pesticides in Bohai Coastal Area (In Chinese). Dalian Maritime University.

Li, Y., Niu, S., Hai, R., Li, M., 2015. Concentrations and distribution of polybrominated diphenyl ethers (PBDEs) in soils and plants from a Deca-BDE manufacturing factory in China. Environ. Sci. Pollut. Res. 22, 1133-1143.

Lin, Z.S., Ma, X.D., Zhang, Q.H., Yao, Z.W., Ma, Y.A., 2008. Study on polybrominated diphenylethers (PBDEs) in sediment surround Bohai Sea (in Chinese). Mar. Environ. Sci. 27, 24-27.

Liu, D., 2013. Polybrominated Diphenyl Ethers in Soils of North China and Human Exposures via Non-dietary Intake (In Chinese). Ocean University of China.

Liu, D., Ma, J., Qiu, X., Zhao, Y., Lin, Y., Yang, Q., Gao, Z., Zhu, T., 2014a. Gridded field observations of polybrominated diphenyl ethers in Soils of North China. Arch. Environ. Contam. Toxicol. 66, 482-490.

Liu, W., Ling, X., Chen, J., Fan, Y., Tao, S., 2008. Geographical distribution of DDTs, PCBs and phthalate esters in coastal surface sediments of Yellow Sea (in Chinese). Environ. Sci. 29, 1761-1767.

Liu, Y., 2010. Distribution and Sources of Persistent Organie Pollutants in Surface Sediments from Bohai Bay (In Chinese). Dalian Maritime University.

Liu, Y., Song, C., Li, Y., Liu, Y., Song, J., 2012. The distribution of organochlorine pesticides (OCPs) in surface sediments of Bohai Sea Bay, China. Environ. Monit. Assess. 184, 1921-1927.

Liu, Y., Wang, J., Tang, J., Yu, Z., Zhang, G., 2014b. Levels, distributions and isomer profiles of hexabromocyclododecanes in the riverine sediments of the Laizhou Bay area, North China (in Chinese). Geochimica 43, 55-63.

Liu, Z., Lu, Y., Wang, T., Wang, P., Li, Q., Johnson, A.C., Sarvajayakesavalu, S., Sweetman, A.J., 2016. Risk assessment and source identification of perfluoroalkyl acids in surface and ground water: Spatial distribution around a mega-fluorochemical industrial park, China. Environ. Int. 91, 69-77.

Lu, J.P., 2015. Pollution Characteristics of Representative Persistent Organic Pollutants in the Aquatic Environment of Liaohe River (In Chinese). Chinese Rearch Academy of Environmental Sciences.

Lu, X., Zhang, S., Chen, C., Hou, Z., Yang, J., 2012. Concentration characteristics and ecological risk of persistent organic pollutants in the surface sediments of Tianjin Coastal Area (in Chinese). Environ. Sci. 33, 3426-3433.

Lu, Y., Wang, L., Huang, J., Wang, T., 2007a. PBDEs in sediments and crucians of Haihe River and Bohai Bay (in Chinese). Environ. Pollut. Control 29, $652-655,660$.

Lu, Y.L., Giesy, J.P., Holliday, L., 2007b. Implementing the Stockholm Convention on Persistent Organic Pollutants. http://www.nap.edu/catalog/11818.html.

Ma, M., Feng, Z., Guan, C., Ma, Y., Xu, H., Li, H., 2001. DDT, PAH and PCB in sediments from the intertidal zone of the Bohai Sea and the Yellow Sea. Mar. Pollut. Bull. $42,132-136$.

Ma, X.D., 2014. Research on Bioconcentration and Biomagniflcation of Polybrominated Diphenyl Ethers and Short-chain Chlorinated Paraffins in a Typical Northern Area of China (In Chinese). Dalian University of Technology.

Men, B., He, M., Tan, L., Lin, C., 2014. Distributions of polychlorinated biphenyls in the Daliao River estuary of Liaodong Bay, Bohai Sea (China). Mar. Pollut. Bull. 78, 77-84.

Meng, J., Wang, T., Wang, P., Zhang, Y., Li, Q., Lu, Y., Giesy, J.P., 2015a. Are levels of perfluoroalkyl substances in soil related to urbanization in rapidly developing coastal areas in North China? Environ. Pollut. 199, 102-109.

Meng, J., Wang, T., Wang, P., Zhu, Z., Li, Q., Lu, Y., 2015b. Perfluoroalkyl substances in Daling river adjacent to fluorine industrial parks: implication from industrial emission. Bull. Environ. Contam. Toxicol. 94, 34-40.

MEP China, 1995. Environmental Quality Standard for Soils (GB-15618-1995) (In
Chinese). Ministry of Environmental Protection of China.

MEP China, 2008. Environmental Quality Standards for Soils (Revised Draft) (GB 15318-2008) (In Chinese). Ministry of Environmental Protection of China.

Moon, H.B., Choi, M., Yu, J., Jung, R.H., Choi, H.G., 2012. Contamination and potential sources of polybrominated diphenyl ethers (PBDEs) in water and sediment from the artificial Lake Shihwa, Korea. Chemosphere 88, 837-843.

Nadal, M., Marques, M., Mari, M., Domingo, J.L., 2015. Climate change and environmental concentrations of POPs: a review. Environ. Res. 143, 177-185.

Naile, J.E., Khim, J.S., Hong, S., Park, J., Kwon, B.O., Ryu, J.S., Hwang, J.H., Jones, P.D. Giesy, J.P., 2013. Distributions and bioconcentration characteristics of perfluorinated compounds in environmental samples collected from the west coast of Korea. Chemosphere 90, 387-394.

Naile, J.E., Khim, J.S., Wang, T., Chen, C., Luo, W., Kwon, B.O., Park, J., Koh, C.H., Jones, P.D., Lu, Y., 2010. Perfluorinated compounds in water, sediment, soil and biota from estuarine and coastal areas of Korea. Environ. Pollut. 158 1237-1244.

Naile, J.E., Khim, J.S., Wang, T., Wan, Y., Luo, W., Hu, W., Jiao, W., Park, J., Ryu, J., Hong, S., Jones, P.D., Lu, Y., Giesy, J.P., 2011. Sources and distribution of polychlorinated-dibenzo-p-dioxins and -dibenzofurans in soil and sediment from the Yellow Sea region of China and Korea. Environ. Pollut. 159, 907-917.

Pan, X., Tang, J., Li, J., Guo, Z., Zhang, G., 2010. Levels and distributions of PBDEs and PCBs in sediments of the Bohai Sea, North China. J. Environ. Monit. 12, $1234-1241$.

Pan, X., Tang, J., Li, J., Zhong, G., Chen, Y., Zhang, G., 2011a. Polybrominated diphenyl ethers (PBDEs) in the riverine and marine sediments of the Laizhou Bay area, North China. J. Environ. Monit. 13, 886-893.

Pan, Y., Shi, Y., Wang, J., Jin, X., Cai, Y., 2011b. Pilot investigation of perfluorinated compounds in river water, sediment, soil and fish in Tianjin, China. Bull. Environ. Contam. Toxicol. 87, 152-157.

POPRC, 2011. Risk Management Evaluation on Hexabromocyclododecane. Report of the Persistent Organic Pollutants Review Committee on the Work of its Seventh meeting: UNEP/POPS/POPRC.7/19/Add.1. UNEP.

Qin, Y.W., Lei, Zhang, Hui, Zheng Bing, Wei, C., 2010. Distribution characteristics and sources of OCPs in estuary sediments of main runoff flowed into Bohai Bay, China (in Chinese). J. Agro Environment Sci. 29, 1900-1906.

Ramu, K., Isobe, T., Takahashi, S., Kim, E.Y., Min, B.Y., We, S.U., Tanabe, S., 2010. Spatial distribution of polybrominated diphenyl ethers and hexabromocyclododecanes in sediments from coastal waters of Korea. Chemosphere 79, 713-719.

Ren, N., Que, M., Li, Y.F., Liu, Y., Wan, X., Xu, D., Sverko, E., Ma, J., 2007. Polychlorinated biphenyls in chinese surface soils. Environ. Sci. Technol. 41, 3871-3876.

So, M., Taniyasu, S., Yamashita, N., Giesy, J., Zheng, J., Fang, Z., Im, S., Lam, P.K., 2004 Perfluorinated compounds in coastal waters of Hong Kong, South China, and Korea. Environ. Sci. Technol. 38, 4056-4063.

Song, C.Z., Zhang, T., Gao, Y.N., Tian, S.Y., 2016. Distribution of polybrominated diphenyl ethers (PBDEs) in river Sediments Entering the Sea in Tianjin area (in Chinese). J. Tianjin Univ. Sci. Technol. 31, 45-50.

Sun, Y., Wang, T., Peng, X., Wang, P., Lu, Y., 2016. Bacterial community compositions in sediment polluted by perfluoroalkyl acids (PFAAs) using Illumina highthroughput sequencing. Environ. Sci. Pollut. Res. 23, 10556-10565.

Tao, S., Liu, W., Li, Y., Yang, Y., Zuo, Q., Li, B., Cao, J., 2008. Organochlorine pesticides contaminated surface soil as reemission source in the Haihe Plain, China. Environ. Sci. Technol. 42, 8395-8400.

Turner, A., Millward, G., 2002. Suspended particles: their role in estuarine biogeochemical cycles. Estuar. Coast. Shelf Sci. 55, 857-883.

Turner, A., Rawling, M.C., 2001. The influence of salting out on the sorption of neutral organic compounds in estuaries. Water Res. 35, 4379-4389.

UNEP, 2001. The 12 Initial POPs under the Stockholm Convention. http://chm.pops. int/TheConvention/ThePOPs/The12InitialPOPs/tabid/296/Default.aspx.

UNEP, 2009. The New POPs under the Stockholm Convention. http://chm.pops.int/ TheConvention/ThePOPs/TheNewPOPs/tabid/2511/Default.aspx.

UNEP, 2013. Listing of Hexabromocyclododecane. https://www.baidu.com/link? url=t3uRuS-skiWTG5ar7-bN9xvh6bs-LzHxSCVKMf7vQky1 bpyqyo2t8COycTR fpVUjyL0CWeB7c7oA84PBtyVLazDEn8u3sM6ccHaHLOcV15mqP-Xas3ITg57 PdVyJjTr\&wd=\&eqid=a86fb13400013df40000000357cac932.

Wang, D.G., Yang, M., Jia, H.L., Zhou, L., Li, Y.F., 2008. Levels, distributions and profiles of polychlorinated biphenyls in surface soils of Dalian, China. Chemosphere 73, 38-42.

Wang, G., Peng, J., Xu, X., Zhang, D., Li, X., 2016. Polybrominated diphenyl ethers in sediments from the Southern Yellow Sea: Concentration, composition profile source identification and mass inventory. Chemosphere 144, 2097-2105.

Wang, G., Peng, J., Yang, D., Zhang, D., Li, X., 2015. Current levels, composition profiles, source identification and potentially ecological risks of polychlorinated biphenyls (PCBs) and polybrominated diphenyl ethers (PBDEs) in the surface sediments from Bohai Sea. Mar. Pollut. Bull. 101, 834-844.

Wang, H., He, M., Lin, C., Quan, X., Guo, W., Yang, Z., 2007. Monitoring and assessment of persistent organochlorine residues in sediments from the Daliaohe river watershed, Northeast of China. Environ. Monit. Assess. 133, 231-242.

Wang, J., Tan, L., Zhang, W., Lian, Z., 2010. Concentrations and distribution characteristic of PAHs,PCBs and OCPs in the surface sediments of Qingdao Coastal area (in Chinese). Environ. Sci. 31, 2713-2722.

Wang, L., 2013. Pollution Characteristics of Organochlorine Pesticides in Daling River Estuary (In Chinese). Dalian Maritime University.

Wang, P., Lu, Y., Wang, T., Fu, Y., Zhu, Z., Liu, S., Xie, S., Xiao, Y., Giesy, J.P., 2014 
Occurrence and transport of 17 perfluoroalkyl acids in 12 coastal rivers in south Bohai coastal region of China with concentrated fluoropolymer facilities. Environ. Pollut. 190, 115-122.

Wang, P., Wang, T., Giesy, J.P., Lu, Y., 2013a. Perfluorinated compounds in soils from Liaodong Bay with concentrated fluorine industry parks in China. Chemosphere 91, 751-757.

Wang, Q., Zhang, Q., Hu, Y., Shi, H., Yin, C., Li, L., 2013b. Distribution and sources of persistent organic pollutants in Bohai Bay (in Chinese). Mar. Environ. Sci. 32, $271-275$.

Wang, T., 2010. Occurrence and Source Apportionment of Persistent Organic Pollutants in Aquatic Environment of Haihe River Estuary (In Chinese). Tsinghua University.

Wang, T., Khim, J.S., Chen, C., Naile, J.E., Lu, Y., Kannan, K., Park, J., Luo, W., Jiao, W., Hu, W., Giesy, J.P., 2012a. Perfluorinated compounds in surface waters from Northern China: Comparison to level of industrialization. Environ. Int. 42 $37-46$

Wang, T., Lu, Y., Chen, C., Naile, J.E., Khim, J.S., Giesy, J.P., 2012b. Perfluorinated compounds in a coastal industrial area of Tianjin, China. Environ. Geochem. Health 34, 301-311.

Wang, T., Lu, Y., Chen, C., Naile, J.E., Khim, J.S., Park, J., Luo, W., Jiao, W., Hu, W., Giesy, J.P., 2011. Perfluorinated compounds in estuarine and coastal areas of north Bohai Sea, China. Mar. Pollut. Bull. 62, 1905-1914.

Wang, Z., Ma, X., Lin, Z., Na, G., Yao, Z., 2009. Congener specific distributions of polybrominated diphenyl ethers (PBDEs) in sediment and mussel (Mytilus edulis) of the Bo Sea, China. Chemosphere 74, 896-901.

Wania, F., Mackay, D., 1996. Peer reviewed: tracking the distribution of persistent organic pollutants. Environ. Sci. Technol. 30, 390A-396A.

Xia, C.H., Lam, J.C.W., Wu, X.G., Sun, L.G., Xie, Z.Q., Lam, P.K.S., 2011. Hexabromocyclododecanes (HBCDs) in marine fishes along the Chinese coastline. Chemosphere 82, 1662-1668.

Xing, Y., Lu, Y.L., Dawson, R.W., Shi, Y.J., Zhang, H., Wang, T.Y., Liu, W.B., Ren, H.C., 2005. A spatial temporal assessment of pollution from PCBs in China. Chemosphere 60, 731-739.

Xu, X. Yang, H., Li, O, Yang, B., Wang, X., Lee, F.S.C., 2007. Residues of organochlorine pesticides in near shore waters of LaiZhou Bay and JiaoZhou Bay, Shandong Peninsula, China. Chemosphere 68, 126-139.

Yang, L., Zhu, L., Liu, Z., 2011. Occurrence and partition of perfluorinated compounds in water and sediment from Liao River and Taihu Lake, China. Chemosphere 83, $806-814$.

Yao, T., He, C., Zhang, P., Gao, H., Zhou, C., 2013. Distribution and sources of polychlorinated biphenyls (PCBs) and organochlorine pesticides (OCPs) in surface waters of Jinzhou Bay in China. Procedia Environ. Sci. 18, 317-322.

Yi, S., Liu, J.G., Jin, J., Zhu, J., 2016. Assessment of the occupational and environmental risks of hexabromocyclododecane (HBCD) in China. Chemosphere 150 $431-437$.

Yuan, J.P., 2013. Study on the Analytical Method and Pollution Characterization of Brominated Flame Retardants in Soil from Yellow River Delta (In Chinese). Shandong University.

Yuan, X., Yang, X., Na, G., Zhang, A., Mao, Y., Liu, G., Wang, L., Li, X., 2015. Polychlorinated biphenyls and organochlorine pesticides in surface sediments from the sand flats of Shuangtaizi Estuary, China: levels, distribution, and possible sources. Environ. Sci. Pollut. Res. 22, 14337-14348.
Zhang, H., Zhao, X., Ni, Y., Lu, X., Chen, J., Su, F., Zhao, L., Zhang, N., Zhang, X., 2010. PCDD/Fs and PCBs in sediments of the Liaohe River, China: levels, distribution, and possible sources. Chemosphere 79, 754-762.

Zhang, K., Wei, Y.L., Zeng, E.Y., 2013a. A review of environmental and human exposure to persistent organic pollutants in the Pearl River Delta, South China. Sci. Total Environ. 463, 1093-1110.

Zhang, K.X., 2011. Occurrence and Risk of Persistent Toxic Substances in Wetland Soils from the Modern Yellow River Delta (In Chinese). Dalian University of Teehnology.

Zhang, P., 2009a. PAHs and PCBs Biogeochemical Characteristics in the Sediments and Coupling with the Eco-Environment in the Bohai Sea and the Southern Yellow Sea (In Chinese). Institute of Oceanology, Chinese Academy of Sciences.

Zhang, P. Song, J., Liu, Z, Zheng, G., Zhang N., He, Z, 2007. PCBs and its coupling with eco-environments in Southern Yellow Sea surface sediments. Mar. Pollut. Bull. 54, 1105-1115.

Zhang, R., Zhang, F., Zhang, T., Yan, H., Shao, W., Zhou, L., Tong, H., 2014. Historical sediment record and distribution of polychlorinated biphenyls (PCBs) in sediments from tidal flats of Haizhou Bay, China. Mar. Pollut. Bull. 89, 487-493.

Zhang, W.H., 2009b. Persistent Organic Pollutants in Surface Sediments and Marine Organisms from Coastal Areas of the Southern Shandong Peninsula (In Chinese). Ocean University of China.

Zhang, Y., Li, Q., Lu, Y., Jones, K., Sweetman, A.J., 2016. Hexabromocyclododecanes (HBCDDs) in surface soils from coastal cities in North China: correlation between diastereoisomer profiles and industrial activities. Chemosphere 148, 504-510.

Zhang, Y., Ruan, Y., Sun, H., Zhao, L., Gan, Z., 2013b. Hexabromocyclododecanes in surface sediments and a sediment core from Rivers and Harbor in the northern Chinese city of Tianjin. Chemosphere 90, 1610-1616.

Zhao, G., Zhou, H., Liu, X., Li, K., Zhang, P., Wen, W., Yu, Y., 2012. PHAHs in 14 principal river sediments from Hai River basin, China. Sci. Total Environ. 427, 139-145.

Zhao, L., Hou, H., Zhou, Y.Y., Xue, N.D., Li, H.Y., Li, F.S., 2010. Distribution and ecological risk of polychlorinated biphenyls and organochlorine pesticides in surficial sediments from Haihe River and Haihe Estuary Area, China. Chemosphere 78, 1285-1293.

Zhao, X., Zhang, H., Ni, Y., Lu, X., Zhang, X., Su, F., Fan, J., Guan, D., Chen, J., 2011. Polybrominated diphenyl ethers in sediments of the Daliao River Estuary, China: levels, distribution and their influencing factors. Chemosphere 82, $1262-1267$

Zhao, Y.Y., 2015. Pollution Status and Migration and Transformation of New Brominated Flame Retardants (In Chinese). Qingdao University.

Zhao, Z., Tang, J., Xie, Z., Chen, Y., Pan, X., Zhong, G., Sturm, R., Zhang, G., Ebinghaus, R., 2013. Perfluoroalkyl acids (PFAAs) in riverine and coastal sediments of Laizhou Bay, North China. Sci. Total Environ. 447, 415-423.

Zhou, M., Oiao, X., Xie, H., Chen, B., Chen, J., Cui, Z., 2012. Concentration and evaluation of HCHs and DDTs in surface sediments of Jiaozhou Bay wetland (in Chinese). Mar. Environ. Sci. 31, 43-47.

Zhu, L., Ma, B., Hites, R.A., 2009. Brominated flame retardants in serum from the general population in Northern China. Environ. Sci. Technol. 43, 6963-6968.

Zhu, Z., Wang, T., Wang, P., Lu, Y., Giesy, J.P., 2014. Perfluoroalkyl and polyfluoroalkyl substances in sediments from South Bohai coastal watersheds, China. Mar. Pollut. Bull. 85, 619-627. 